\title{
Expedições científicas, fotografia e intenção documentária: as viagens do Instituto Oswaldo Cruz (1911-1913)
}

\author{
Scientific expeditions, photography, and documental intent: the \\ Oswaldo Cruz Institute expeditions (1911-1913)
}

\section{Maria Teresa Villela Bandeira de Mello \\ Historiadora do Arquivo Público do \\ Estado do Rio de Janeiro \\ Rua Gavião Peixoto, 332/902 \\ 24230-103 - Niterói - RJ - Brasil \\ tetebandmello@hotmail.com}

Fernando A. Pires-Alves

Historiador da Casa de Oswaldo Cruz/ Fundação Oswaldo Cruz

Avenida Brasil, 4.036/414 21040-361 - Rio de Janeiro - RJ -

Brasil

fapires@coc.fiocruz.br
MELLO, Maria Teresa Villela Bandeira de; PIRES-ALVES, Fernando. Expedições científicas, fotografia e intenção documentária: as viagens do Instituto Oswaldo Cruz (1911-1913). História, Ciências, Saúde Manguinhos, Rio de Janeiro, v.16, supl.1, jul. 2009, p.139-179.

\section{Resumo}

Analisa as séries fotográficas produzidas pelo Instituto Oswaldo Cruz em expediç̃es científicas ao interior do Brasil, realizadas entre 1911 e 1913. Detém-se na expedição liderada por Arthur Neiva e Belisário Penna e na elaboração do seu discurso documentário. Explicita escolhas e ênfases adotadas na elaboração de cada texto visual, expresso tanto no material produzido durante o percurso quanto na seleção das imagens para publicação. As análises quantitativa e qualitativa das imagens da expedição de Neiva e Penna revelam um percurso narrativo que articula o meio natural, a vida social e as evidências de adoecimento das populações interioranas, para a constituição de um discurso que difunde o movimento pelo saneamento dos sertões.

Palavras-chave: fotografia; documentação histórica; história da saúde pública no Brasil; expedições científicas; Instituto Oswaldo Cruz.

\begin{abstract}
The article analyzes the photographic series produced by the Oswaldo Cruz Institute in reference to scientific expeditions into the interior of Brazil between 1911 and 1913, with a special focus on the one headed by Arthur Neiva and Belisário Penna and on the development of their documentary discourse. It draws out the choices and emphases used in preparing each visual text, expressed both in the material produced during the journeys and in the process of selecting images for publication. The study's quantitative and qualitative analyses of images from the Neiva-Penna expedition uncover a narrative journey that articulates the natural environment, social life, and evidence of the sickly status of residents of the interior to shape a discourse that disseminates the nascent movement to sanitize the sertão regions.
\end{abstract}

Keywords: photography; historical documentation; history of public health in Brazil; scientific expeditions; Oswaldo Cruz Institute.

Recebido para publicação em maio de 2008.

Aprovado para publicação em março de 2009. 
$\mathrm{O}$ presente artigo discute a utilização da fotografia na construção do conhecimento histórico e realiza um estudo de caso compreendendo uma análise quantitativa, comparativa e qualitativa de séries fotográficas produzidas e publicadas por cinco expedições científicas ao interior brasileiro, empreendidas por médicos e pesquisadores do Instituto Oswaldo Cruz, entre 1911 e 1913. O trabalho está dividido em quatro partes. Na primeira parte é realizada uma ligeira revisão das abordagens teóricas relativas ao uso de imagens fotográficas como fonte de conhecimento histórico. No segundo segmento são descritas sumariamente as expedições científicas que serão objeto de análise, assim como o seu contexto de realização. Na terceira parte opera-se a quantificação e comparação entre as séries fotográficas, explicitando-se as diferenças entre as intenções documentárias presentes em cada empreendimento. Por fim, na quarta seção, a análise, que combina aspectos quantitativos e qualitativos, concentra-se sobre as imagens selecionadas por Arthur Neiva e Belisário Penna para a publicação do relatório da viagem por eles empreendida pelas regiões Nordeste e Centro-oeste do país.

A análise comparada é apresentada em detalhe, explicitando-se as precauções metodológicas quanto à organicidade e integridade de cada um dos conjuntos fotográficos analisados, assim como as operações de classificação e análise propriamente ditas. Ao seu término, será possível concluir, pelo menos para um subconjunto de expedições, sobre o protagonismo das lideranças médicas na definição do olhar documentário e do discurso visual de cada expedição. Será possível, também, estabelecer as marcas distintivas de cada expedição, no que concerne às escolhas de temas como objeto de registro e à ênfase atribuída a cada um desses temas.

A análise mais detida sobre os registros produzidos durante a expedição liderada por Arthur Neiva e Belisário Penna ao interior das regiões Nordeste e Centro-oeste do país, assim como a análise dos materiais selecionados para a publicação do seu relatório de viagem, revela a elaboração de um texto visual capaz de funcionar autonomamente. Como se verá, todavia, foi a partir das relações de intertextualidade com o contexto discursivo no qual emergiu que o texto visual então elaborado encontrou seu maior vigor. É, inclusive, como componente dessas relações discursivas que ele pode ser melhor mobilizado como fonte histórica.

\section{Fotografias e conhecimento histórico: aspectos teóricos}

A crescente utilização de imagens como fonte para a história, verificada nos últimos anos, é decorrente de uma profunda reformulação nos paradigmas, objetos e métodos das ciências humanas a partir da segunda metade do século XX. A influência da École des Annales e o surgimento de questionamentos relativos ao estatuto da história como forma de conhecimento fizeram com que os historiadores ampliassem consideravelmente seus interesses e abordagens, produzindo ou descobrindo novos objetos, entre eles o corpo, o cotidiano, as mentalidades e a cultura material, ao lado da manutenção das antigas referências ao político e às estruturas econômicas e sociais. As fontes tradicionais de pesquisa revelaram-se insuficientes para dar conta dos temas que passaram a integrar o novo campo 
de trabalho do historiador e outros tipos de documentos foram incorporados a esse universo, entre eles a produção literária, os depoimentos orais e as imagens.

Essa renovação na história compreendeu também uma abertura conceitual e metodológica, aproximando-a das outras ciências humanas e estabelecendo um diálogo fundamental para a interpretação desses documentos, até então pouco convencionais no ofício do historiador, acarretando uma transdisciplinaridade que vem marcando e enriquecendo a produção nessa área, principalmente a partir da década de 1980.

Entretanto, como aponta Meneses (2003, p.12), ao se aproximar do campo visual o historiador reteve, quase sempre, exclusivamente a imagem - transformada em fonte de informação -, ignorando o potencial da visualidade como uma dimensão importante da vida social e dos processos sociais. Para ele, diferentemente da história da arte, antropologia e sociologia, a história como disciplina continuaria à margem dos esforços realizados no campo das demais ciências humanas e sociais, no que se refere não só a fontes visuais como também à problemática básica da visualidade. Sendo assim, enquanto as demais disciplinas desenvolveram uma tradição de uso documental da imagem a partir do reconhecimento de seu potencial cognitivo, a história continuou a privilegiar a função da imagem com a qual ela penetrou suas fronteiras no final do século XX: o uso como ilustração.

Essa tendência - a da imagem como ilustração - torna-se mais forte ainda em relação às imagens fotográficas, em virtude de sua natureza mecânica e referencial. Por apresentar características como rapidez, exatidão e reprodutibilidade, a fotografia suscitou a crença de que seria uma técnica exata de reprodução do real. Essa ideia de 'duplicação do real' enfatizou o caráter objetivo da imagem fotográfica, encarada como o processo mais fiel e imparcial de representação da realidade, acompanhando seus usos em diversas áreas do conhecimento científico, inclusive na História, durante muito tempo (Mello, 2007, p.10-11; Lacerda, Mello, 2003, p.540-541).

A noção de técnica exata de reprodução do real atribuída à fotografia foi reforçada por uma de suas características essenciais: a necessidade da presença física do referente (pessoa, objeto, tema) por ocasião da produção do registro. As questões relativas à natureza específica da imagem fotográfica acarretaram tanto o surgimento dos primeiros trabalhos na linha de uma teoria da fotografia, quanto repercussões nas histórias e teorias da arte e das demais ciências humanas. Essas discussões foram ampliadas e enriquecidas a partir da década de 1950, com o desenvolvimento da semiologia e da semiótica, que tiveram enorme influência nos estudos envolvendo imagens visuais.

Entretanto durante muito tempo os historiadores, de maneira geral, ignoraram as fontes iconográficas enquanto tais. Restritos aos documentos escritos, só recorriam a elas sob a forma de ilustrações, muitas vezes tomadas como autoevidentes e autoexplicativas, desprezando, por conseguinte, aquilo que tinham de mais significativo: suas relações com os momentos históricos nos quais vieram à luz.

Para Knauss (2006, p.101-102), as leituras tradicionais da historiografia tendem a reconhecer somente as práticas de estudo da história que se assemelham ao modelo da história científica consagrada a partir do século XIX. Essas leituras caracterizam a constituição de uma memória disciplinar. Nesse percurso definiu-se o uso das fontes escritas 
como padrão geral de avaliação das práticas de investigação histórica. O documento escrito se impôs como padrão de fonte histórica. A concepção de documento se definiu como prova dos fatos. Esse modelo foi validado pela concepção cientificista de documento e traduziu a afirmação da objetividade do conhecimento como dado. Entretanto a crítica contemporânea à concepção cientificista da história conduziu também à crítica da concepção correspondente de documento histórico e à revalorização das imagens como fontes de representações sociais e culturais. Nesse sentido a historiografia contemporânea promoveu, em certa medida, um reencontro com o estudo das imagens.

O envolvimento contemporâneo com os questionamentos e as problematizações em torno da imagem resultou na construção de um novo campo interdisciplinar de pesquisa que tem como objeto de investigação a cultura visual. Esse campo, chamado de 'estudos visuais', institucionalizou-se na década de 1990 a partir dos Estados Unidos e da Inglaterra. É importante observar que a emergência dos estudos sobre a cultura visual está marcada pela interseção com os estudos culturais. Foi no início da década de 1980 que o estudo da cultura se tornou central para as ciências humanas e conduziu a uma revisão do estatuto do social. Nesse contexto o lado subjetivo das relações sociais ganhou espaço e consolidou uma tendência que passou a sublinhar o modo pelo qual a cultura - o sistema de representações - instigava as forças sociais de um modo geral, não sendo mero reflexo de movimentos da política ou da economia. A cultura visual seria, portanto, um desdobramento do movimento geral de interrogação também sobre a própria cultura, em termos abrangentes (Knauss, 2006, p.107).

O conceito de cultura visual não tem o mesmo sentido para os autores que se debruçaram sobre o tema: eles provêm de escolas de pensamento diferentes, moldadas a partir de opções conceituais distintas, definindo diversas orientações de trabalho, nem sempre complementares. Entretanto podemos identificar duas linhas principais de interpretação, que definem a cultura visual ora de modo abrangente, ora de modo estrito. A definição abrangente aproxima o conceito de cultura visual da diversidade do mundo das imagens, das representações visuais, dos processos de visualização e de modelos de visualidade. Um de seus representantes, Mitchel (1994), utiliza-se da expressão pictorial turn para tratar a discussão teórica que se desenvolveu sobre a imagem. Esse termo é tomado emprestado do filósofo Richard Rorty, para quem a história da filosofia é marcada por uma série de viradas, ou reviravoltas. Rorty trata especificamente da chamada 'virada linguística', ou linguistic turn, fenômeno que se verificou a partir do final da década de 1950, quando se passou a dar destaque, na crítica das artes e das formas culturais, aos diversos modelos de textualidade e discursos. Para Mitchel, o pictorial turn representaria a 'virada pictórica', enfatizando o figurado como representação visual. Ainda segundo esse autor, o campo de estudos da cultura visual poderia ser definido como o estudo das construções culturais da experiência visual na vida cotidiana, assim como nas mídias, representações e artes visuais. O cultural é visto como a ordem de imagens e mediações que tornam a sociedade possível.

Martin Jay (Brennan, Jay, 1996, p.1-14), por sua vez, sublinha a importância assumida pelos 'modos de ver' e pela experiência visual como paradigma da nossa época, apontando que o modelo de leitura de textos tradicional é recusado pelo novo paradigma e substituído por modelos de visualidade e de espectadores. O figurado resiste aos parâmetros da 
discursividade e impõe um modo de análise próprio, que valoriza o estudo da percepção e abre o campo para interpretações históricas e culturais. Dessa forma, é fundamental não tomar a visão como um dado natural e questionar a universalidade da experiência visual: admitir a especificidade cultural da visualidade para caracterizar transformações históricas da visualidade e contextualizar a visão. $\mathrm{O}$ advento da cultura visual seria, então, decorrente do fato de que não podemos mais separar os objetos visuais de seu contexto.

Tanto Mitchell quanto Jay tomam os estudos culturais como referência para a discussão sobre a cultura visual afirmando uma orientação de estudo comum, que parte da definição das representações como práticas de significação. A centralidade estaria posta na cultura, uma vez que se considera que toda prática social depende dos seus sentidos.

Em outra direção, encontramos a linha de reflexão que define a cultura visual de modo restrito. Um dos principais representantes dessa linha é Chris Jenks (1995, p.1-25). Afirma o autor que a cultura ocidental é definida pela centralidade do olhar. Esse 'ocularcentrismo' estabeleceria a primazia do olhar como recurso para relacionar uma natureza exterior com uma mente interior, o que traduziria a metodologia da observação e o princípio epistemológico do pensamento científico ocidental. A possibilidade de interrogação sobre o olhar ocidental parte do pressuposto de que os modos de ver são definidos como visões parciais do mundo, que, por meio de representações visuais, reordenam o mundo a partir do olhar.

Mirzoeff (1999, p.1-33), por sua vez, enfatiza a necessidade de o estudo da cultura visual se posicionar como o estudo crítico da cultura global da visualidade, sob domínio da mediação tecnológica baseada na imagem digital ou virtual. Para ele, o desenvolvimento recente da tecnologia digital seria a causa de mudanças culturais importantes que deram lugar à preeminência do visual na vida cotidiana. Nesse sentido, a cultura visual seria uma tática, uma forma de abordagem para estudar o modo de vida contemporâneo do ponto de vista do consumidor, interrogando-se como são buscadas informações e prazer por esse consumidor/ receptor através da tecnologia visual ou dos aparatos concebidos para intensificar o olhar.

Apesar das diferentes escolas de pensamento e orientações de trabalho, podemos dizer que o principal enfoque comum aos estudos visuais é a valorização da discussão sobre o papel do visual no mundo atual. É possível dizer que, a partir dos estudos culturais, o foco da cultura visual dirigiu-se para a análise da imagem como representação visual, resultado de processos de produção de sentido em contextos culturais.

A postura que compreende o processo social como dinâmico e de múltiplas dimensões abre espaço para que a história tome como objeto de estudo as formas de produção de sentido. O pressuposto de seu tratamento é compreender os processos de produção de sentido como processos sociais. Os significados não são tomados como dados, mas como construção cultural. Isso abre um campo para o estudo dos diversos textos e práticas culturais, admitindose que a sociedade se organiza, também, a partir do confronto de discursos e leituras de textos de qualquer natureza - verbal escrito, oral ou visual (Knauss, 2006, p.100). Sendo assim, os estudos visuais - seguindo a tradição dos estudos culturais - defendem que os sentidos não estão investidos nos objetos. Pelo contrário, o conceito de cultura visual sustenta o pressuposto de que os significados estão investidos nas relações humanas. O objeto individual é integrado numa ampla rede de associações e de valores que integram as competências visuais (p.114). Uma das principais contribuições desse novo campo de 
investigação é a definição das representações visuais como práticas de significação. As imagens são ferramentas de percepção da produção de sentido. $\mathrm{O}$ tratamento que deve ser dado a elas supõe que esse significado, como produção de sentido, revela os elementos estruturais dos processos sociais.

Outro elemento fundamental, resultante do desenvolvimento do campo da cultura visual, bem como da interdisciplinaridade entre as ciências humanas, é a noção de intertextualidade. O questionamento sobre a autonomia do visual e seus limites é colocado de modo a afirmar que a visão deve ser tratada como matriz que inclui outros sentidos. É assim que Mitchell (1994) condena a separação do verbal e do visual e afirma que a tensão entre a palavra e a imagem é insuperável. Ao propor o diálogo permanente entre representações verbais e representações pictóricas, ele sublinha que as representações visuais fazem parte de um conjunto entrelaçado de práticas e discursos. Nesse sentido, Mitchell defende o estudo da imagem como um jogo complexo entre visualidade, aparatos, instituições, discursos, corpos e figuração. Cada um dos termos indica um complexo conjunto de práticas subjacentes que tornam possível a imagem e sua capacidade de conter significado. 'Visualidade', aqui, se refere ao registro visual em que a imagem e o significado visual operam, e o 'aparato' diz respeito ao domínio do meio de expressão que condiciona a produção e circulação das imagens.

Com relação às instituições, é importante observar as relações sociais organizadas em torno da imagem e da sua circulação. Os corpos, por sua vez, remetem à necessidade de considerar a presença do observador/espectador, necessário nos circuitos da promoção do significado visual. O plano da figuração não permite esquecer que as imagens têm papel privilegiado, no sentido de representar ou figurar o mundo em formas visuais. No entanto esses planos não podem ser tomados individualmente e devem ser considerados, em termos de relações externas, uns em relação aos outros.

Na mesma direção caminham os trabalhos de Marita Sturken e Lisa Cartwright, quando observam que a experiência visual não se realiza de modo isolado, e que nós fazemos associações com outros tipos de imagens e outras áreas de nossas vidas informadas por imagens visuais. Os significados seriam produzidos no processo de negociação entre os indivíduos numa determinada cultura, e entre indivíduos e os artefatos, imagens e textos criados por eles mesmos e pelos outros. A cultura é tomada como um processo fluido e interativo, fundamentado em práticas sociais e não apenas em imagens, textos ou interpretações. Nesse sentido, fundamentar o 'visual' na cultura visual não significa separar as imagens da escrita, do discurso, da linguagem ou de outros modos de representação e experiências (Sturken, Cartwright, 2001, p.1-9). Surge, aqui, outra noção fundamental que pode enriquecer as abordagens e análises em torno das imagens visuais, em especial das fotografias. Trata-se da noção de artefato cultural, através da qual se pretende dar materialidade às imagens.

Para alguns autores (Meneses, 2002, 2003; Edwards, 1997; Edwards, Hart, 2004, 1997; Wells, 1997), a abordagem mais interessante atualmente, para se trabalhar com imagens, é incluir a materialidade das representações visuais no horizonte das preocupações e entender as imagens como 'coisas' que participam das relações sociais e, mais que isso, como 'práticas 
materiais'. Sob tal perspectiva, a imagem é considerada não somente como documento, mas também como objeto material, artefato cultural.

Segundo Meneses (2003), é necessário 'tomar' as coisas visuais como 'coisas', que se prestam a diversos usos, entre os quais os documentais, conforme as situações. É preferível considerar a fotografia como parte viva de nossa realidade social. Vivemos a imagem em nosso cotidiano, em várias dimensões, usos e funções. O emprego de imagens como fonte de informação é apenas um entre tantos (inclusive simultaneamente a outros) e não altera a natureza da 'coisa', mas se realiza efetivamente em situações culturais específicas entre várias outras. A mesma imagem, portanto, pode reciclar-se, assumir vários papéis, ressemantizar-se e produzir efeitos diversos (p.29). As imagens contam apenas com atributos físico-químicos intrínsecos. É a interação social que produz sentidos, mobilizando diferencialmente determinados atributos para dar existência social a sentidos e valores e fazê-los atuar: "É necessário tomar a imagem como um enunciado, que só se apreende na fala, em situação. Daí também a importância de retraçar a biografia, a carreira, a trajetória das imagens" (p.28-29).

Em síntese, o que nos parece fundamental é que a interface da história com outras disciplinas das ciências humanas e sociais, característica de muitos trabalhos historiográficos recentes, tem-se mostrado bastante profícua para uma melhor compreensão do estatuto da fotografia e para o estabelecimento de uma linha de reflexão sobre sua função como documento histórico. A resultante mais significativa dessa proposta transdisciplinar, para nossa abordagem, é a noção de fotografia como resultado de um trabalho social de produção de sentido, fundamentado sobre códigos convencionalizados culturalmente. A fotografia "é uma mensagem que se processa através do tempo, cujas unidades constituintes são culturais, mas assumem funções sígnicas diferenciadas, de acordo tanto com o contexto no qual a mensagem é veiculada, quanto com o local que ocupam no interior da própria mensagem" (Mauad, 1996, p.84).

Tomando essa premissa como ponto de partida, muitos historiadores têm-se voltado para a análise das relações entre fotografia e história, seja na linha da própria história da fotografia, buscando estabelecer os vínculos e os processos de evolução da técnica fotográfica e sua inserção social - seus usos e funções -, ou investigando seu papel na construção do conhecimento histórico. O elemento comum, nesses trabalhos, é o reconhecimento de que a fotografia é um ponto de interseção de várias ações e ordens de pensamentos relacionados à sua produção, publicização, consumo e 'leitura': ela é um signo visual, produzido e utilizado em contextos específicos e diferenciados. A imagem fotográfica não tem um sentido único, puro, imanente, encerrado em si própria (Mello, 2007, p.12). Nesse sentido, o maior desafio é estabelecer relações e nexos entre aquilo que, de maneira específica, caracteriza o 'fotográfico' (sua qualidade referencial), os discursos teóricos e as práticas metodológicas (oriundos de várias áreas do conhecimento) que propiciem o entendimento dos contextos de produção, circulação e consumo dessas imagens e auxiliem na sua interpretação.

Como aponta Mauad (2005, p.142), a compreensão da imagem fotográfica pelo leitor/ destinatário dá-se em dois níveis: o nível interno à superfície do texto visual, originado a partir das estruturas espaciais que constituem tal texto, de caráter não-verbal; e o nível 
externo à superfície do texto visual, originado a partir de aproximações e inferências com outros textos da mesma época, inclusive de natureza verbal. Nesse nível, pode-se descobrir temas conhecidos e inferir informações implícitas. A compreensão de textos visuais é tanto um ato conceitual (os níveis externo e interno encontram-se necessariamente em correspondência no processo de conhecimento), quanto um ato fundado numa pragmática, que pressupõe a aplicação de regras culturalmente aceitas como válidas e convencionalizadas na dinâmica social (p.142).

A fotografia, juntamente com outros textos de caráter verbal e não-verbal, forma a textualidade de uma determinada época. As fotografias, assim como os demais textos históricos, não são autônomas e necessitam de outros textos para sua interpretação. Nessa perspectiva, para utilizarmos a fotografia como fonte histórica é fundamental a noção de 'série', série extensa e homogênea. Essa noção implica uma dinâmica entre as imagens que se relacionam em função de um tema, de uma missão fotográfica ou de um produtor e podem dar conta das semelhanças e diferenças entre si. Uma fotografia isolada, assim como qualquer outro tipo de documento, não pode dar conta do complexo significado do processo histórico.

Esses pressupostos teórico-metodológicos servirão de base para a nossa análise em torno das imagens fotográficas das expedições científicas do Instituto Oswaldo Cruz, no início do século XX. Nesse sentido, assumindo a postura metodológica que trabalha a partir do reconhecimento da materialidade das fotografias, buscamos, ao longo de nossa análise, identificar e reconhecer diversos aspectos que envolvem a natureza técnica, os contextos de produção, circulação e consumo dessas imagens e as questões específicas relacionadas aos seus elementos constitutivos. Só assim será possível restabelecer as condições de emissão e recepção da mensagem fotográfica, bem como as tensões sociais que envolveram a sua elaboração. Dessa forma, texto e contexto são contemplados.

Sendo assim, as fotografias das expedições científicas do Instituto Oswaldo Cruz são aqui tomadas como índices, como registros e testemunhos de uma determinada época e de ações empreendidas pelo mais importante instituto científico do país, mas que, simultaneamente, estão inseridas nos processos de produção de sentido na sociedade contemporânea e que podem tomar e agregar outras funções e usos ao longo da sua história. É o caso, por exemplo, dos registros fotográficos produzidos durante as viagens pelo interior do Brasil, que podem tomar outros significados e papéis ao serem publicizadas nos relatórios de viagens publicados nas Memórias do Instituto Oswaldo Cruz.

$\mathrm{Na}$ terceira seção deste artigo é realizada uma análise quantitativa comparada dos registros fotográficos produzidos por cinco expedições cientificas ao interior brasileiro, empreendidas por médicos e pesquisadores do Instituto Oswaldo Cruz entre 1911 e 1913. Trata-se, principalmente, de ensaio metodológico que pretende obter informações históricas a partir do exame de séries fotográficas dadas. A perspectiva metodológica procura isolar e comparar, quando possível e pertinente, os elementos estruturais do registro fotográfico. Para tanto são mobilizadas, pelo menos parcialmente, as proposições formuladas por Mitchell (1994).

Os elementos determinantes da imagem fotográfica conformam uma mediação entre um dado momento do real e a materialização parcial de um determinado objeto-imagem. 
Assim, para as operações realizadas nesta análise, assumem relevância a noção de visualidade, segundo a qual determinados componentes visuais da realidade se tornam apreensíveis pelo observador e passíveis de inclusão em um enunciado; as de fotógrafo e instituições, assim como a de aparatos, designando o instrumental tecnológico que propicia e condiciona as possibilidades de registro.

A opção do fotógrafo por determinado assunto ou tema e por determinada visualidade é função do seu estar no mundo, de suas possibilidades cognitivas e de observação, das quais a própria tecnologia é parte componente, mais do que simples mediação. Em termos resumidos, é nele que se concentram os atributos que definem o recorte do real a ser congelado e eternizado. É a partir do seu 'olhar' que, dada uma determinada possibilidade técnica, toma forma o que virá a ser determinado registro: o que deverá ser registrado, de que maneira e, muitas vezes, quando.

As instituições, por outro lado, multiplicam esses pontos de vista. Podem ser de fato distintos os olhares de um fotógrafo, quando maneja seu equipamento segundo os seus interesses individuais e quando trabalha por encomenda, segundo os interesses de um contratante. Nessas situações o que se observa é que o fotógrafo passa a representar uma espécie de 'olhar' combinado de fotógrafo-contratante. ${ }^{1}$ No caso das expedições científicas do Instituto Oswaldo Cruz - que examinaremos mais de perto - essa combinação torna-se - pelo menos como possibilidade a ser considerada - a resultante de uma tríade onde interagem (a) o 'olhar' dos fotógrafos; (b) os pesquisadores e outros profissionais que lideram cada uma das expedições; e (c) as instituições que as promovem e realizam.

Nas expedições do Instituto Oswaldo Cruz, o trabalho do fotógrafo foi direta e continuamente acompanhado por personagens que não só representavam uma ou mais instituições contratantes interessadas em uma determinada orientação documentária. Como se verá, a análise comparada entre as imagens registradas pelas expedições e aquelas que foram publicadas junto aos relatórios, em Memórias do Instituto Oswaldo Cruz, parece indicar que, em parte importante daquelas expedições, foi exatamente a intenção documentária dos médicos-líderes de cada expedição a que prevaleceu na produção dos registros fotográficos. Da mesma forma, as eventuais variações na frequência de ocorrências temáticas observadas entre essas mesmas expedições evidenciam que seus chefes eram portadores de intenções documentárias também diversas.

Antes de avançarmos, porém, sobre a análise dos conjuntos fotográficos, tratamos de apresentar essas expedições científicas em seu contexto histórico. ${ }^{2}$

\section{As expedições científicas e seu contexto histórico}

No começo da década de 1910, o Instituto Oswaldo Cruz, fundado em 1900 como modesto instituto soroterápico com o objetivo imediato e restrito de produzir soros e vacinas contra a peste bubônica, consolidava-se institucionalmente como centro de medicina experimental vinculado à estrutura da Diretoria Geral de Saúde Pública, e onde se articulavam as atividades de pesquisa com vistas à geração de conhecimentos originais, à produção de medicamentos e ao ensino de microbiologia. A história do Instituto nas suas primeiras duas décadas de existência esteve essencialmente associada à trajetória de 
Oswaldo Cruz, como seu diretor, desde finais de 1902 até 1914, e como diretor geral de Saúde Pública, entre 1903 e 1909.

O significativo êxito das campanhas conduzidas por Oswaldo Cruz no combate à febre amarela, à peste e à varíola no Rio de Janeiro, e o reconhecimento internacional desses sucessos tornou o Instituto e a Diretoria Geral de Saúde Pública parceiros dos mais importantes nas iniciativas do governo federal que tinham em vista a modernização da capital da República e do país em áreas como energia, transporte ferroviário e infraestrutura portuária. Assim, em várias ocasiões Oswaldo Cruz e seus auxiliares diretos estiveram presentes na inspeção das condições sanitárias de portos brasileiros, ou debelando surtos epidêmicos nas capitais dos estados e cidades mais importantes, ou controlando a malária nos canteiros de obras de usinas hidroelétricas, de mananciais de captação de água e de instalação de linhas férreas, entre outros empreendimentos. ${ }^{3}$

Regularmente os médicos do Instituto associavam o desempenho dessas missões sanitárias, mais ou menos tópicas, à investigação científica não orientada a uma aplicação imediata. Assim, por exemplo, em 1907, na localidade de Lassance (MG), Carlos Chagas - ao mesmo tempo que assessorava, com Belisário Penna, a Estrada de Ferro Central do Brasil (EFCB) no controle da malária nas obras de prolongamento da linha do centro até Pirapora (MG) dava início a uma atividade de investigação que culminou na identificação de uma tripanossomíase desconhecida, seu agente etiológico, o vetor, e seus reservatórios domésticos e silvestres. Uma patologia que mais tarde receberia seu nome: a doença de Chagas.

O que se deve ter em mente é que esses médicos, que logo estariam liderando extensas incursões ao interior do país, combinavam em suas atividades e em suas próprias identidades profissionais dois papéis distintos, ainda que não antagônicos: o do higienista, atento ao combate e à prevenção de doenças em sua dimensão coletiva, e o do pesquisador de laboratório interessado em estabelecer, em termos pasteurianos, os agentes microbianos causais, a etiologia e, se possível, as formas de imunização e cura dessas doenças. ${ }^{4}$

Outra dimensão contextual a ser considerada diz respeito ao ambiente intelectual no qual se inseriam, como parte de uma elite culta, os médicos do Instituto de Manguinhos e das demais instâncias da saúde pública. Como bem assinala Nicolau Sevcenko (1983, p.41-42), a Regeneração, termo cunhado pelos cronistas da primeira década do século ao se referirem às transformações do espaço público da capital da República, não deve ser considerada restrita a esse âmbito. Considerando os hábitos, os costumes e os padrões das relações sociais referidos à sociedade imperial, ela tem um aspecto material mais vasto ainda: reporta à modernização da capital, incluindo a criação de troncos ferroviários, a melhoria dos portos, a cartografia do território e implantação de linhas telegráficas, a modernização das forças armadas e a emergência de estrutura burocrática moderna.

Assim, as motivações dos órgãos administrativos que promoveram as expedições do Instituto Oswaldo Cruz, do mesmo modo que investidas assemelhadas como as chefiadas por Candido Mariano Rondon e as conduzidas pela Comissão Geológica de São Paulo, por exemplo, são bastante típicas de uma nova atitude republicana e apontam para dois aspectos fundamentais. ${ }^{5} \mathrm{O}$ primeiro deles seria a necessidade da criação de um saber próprio sobre o Brasil, de larga base empírica, como única forma de garantir abordagem e solução adequadas dos problemas nacionais. O segundo aponta a necessidade de conhecer e integrar 
socioeconômica e culturalmente o interior brasileiro. Pronunciamentos dessa ordem exigiam que esforços de modernização avançassem território adentro, não se restringindo apenas a um embelezamento cosmético da capital e à introdução de poucas comodidades em cidades consideradas mais importantes (Torres, 1978, p.46).

Assim, na primavera de 1911, deu-se o início de um ciclo de longas e demoradas viagens médico-sanitárias, pondo seus líderes a caminho, certamente imbuídos desse sentido de missão, a um só tempo patriótica e civilizatória. Entre setembro de 1911 e fevereiro de 1912, o médico e pesquisador Astrogildo Machado e o farmacêutico Antonio Martins, ambos do Instituto Oswaldo Cruz, propiciaram apoio médico-sanitário aos engenheiros e topógrafos da EFCB, que sob a liderança de Adolfo Pereira tinham por missão estabelecer o traçado definitivo daquela que era denominada A Longitudinal: um prolongamento da linha ferroviária que, partindo de Pirapora, no noroeste mineiro, e tomando sentido norte deveria alcançar Belém do Pará. Foram acompanhados pelo fotógrafo João Stamato e por Cipriano Segur, seu auxiliar. As equipes percorreram os vales do São Francisco e do Tocantins e, após alcançarem a capital paraense, retornaram ao Rio de Janeiro por via marítima.

A partir do mês de março de 1912 iniciaram-se três viagens patrocinadas pela Inspetoria de Obras contra as Secas. Acreditava-se que fossem capazes de proporcionar conhecimentos sobre geografia, zoologia, botânica, e condições sanitárias da região, de modo a criar fundamentos seguros para as ações práticas da Inspetoria. Arthur Neiva e Belisário Penna percorreram o norte da Bahia, o sudeste de Pernambuco, o sul do Piauí e Goiás de norte a sul. Para o Ceará e o norte do Piauí dirigiam-se João Pedro de Albuquerque e José Gomes de Faria. Ambas as expedições deixaram o porto do Rio de Janeiro no dia 18 daquele mês, a bordo do mesmo vapor, de nome algo simbólico: Brasil. A viagem de Neiva e Penna encerrouse em outubro, tendo durado longos sete meses e percorrido sete mil quilômetros. Da expedição de Albuquerque e Gomes de Faria pouco se sabe, não sendo conhecidos relatórios ou outros materiais textuais.

Em 17 de abril do mesmo ano Astrogildo Machado deu início à terceira expedição chancelada pela Inspetoria de Obras Contra as Secas, dessa vez em companhia de Adolpho Lutz. Após dirigir-se por trem a Pirapora, percorreu o rio São Francisco até Juazeiro, a bordo de um gaiola, visitando também alguns de seus afluentes. Essa viagem fluvial transcorreu até julho de 1912, quando iniciou seu regresso ao Rio de Janeiro.

De todas as expedições da Inspetoria, conhece-se apenas o fotógrafo daquela liderada por Neiva e Penna: José Teixeira - sobre quem, contudo, ignora-se se tinha outras atividades profissionais.

A serviço da Superintendência da Defesa da Borracha, Carlos Chagas, Pacheco Leão e João Pedro de Albuquerque realizaram a quarta e última grande expedição do período. Inspecionaram boa parte da Bacia Amazônica, em especial o trecho acima de Manaus. Seus objetivos somavam-se àqueles de outras missões destinadas a prover de conhecimentos e meios tecnocientíficos a implementação de um Plano de Defesa da Borracha, cuja exploração começava a viver acentuado declínio, devido à concorrência das plantações do Oriente, mais racionais e produtivas que a extração selvagem.

As intervenções anteriores do Instituto Oswaldo Cruz, em apoio a obras e a outras iniciativas modernizadoras, principalmente visavam resultados imediatos em áreas 
geográficas relativamente restritas e, acessoriamente, possibilitavam a realização de trabalhos de investigação originais. Já as expedições patrocinadas pela Inspetoria de Obras Contra as Secas e pela Superintendência de Defesa da Borracha percorreram extensas regiões do território com um programa de trabalho que privilegiava a investigação exploratória. Seus resultados se traduziram ora na aquisição de novos espécimes para as coleções científicas do Instituto Oswaldo Cruz, ora na descrição de novas patologias e no estabelecimento de um novo quadro nosológico das regiões interioranas, e proporcionaram, em alguns casos, descrições inquietantes dos aspectos econômicos, sociais e culturais dessas regiões.

A análise comparativa de cada coleção de fotografias e dos relatórios ilustrados publicados indica que cada expedição era portadora de uma intenção documentária própria, tendo elaborado o seu próprio texto fotográfico. Nossa análise explicita essas distinções e avança sobre as especificidades e a singularidade do perfil documentário da expedição de Neiva e Penna e do discurso iconográfico presente em seu relatório. Sem dúvida ela também contribuiu para enriquecer o acervo de informações disponíveis e para descortinar novas possibilidades de investigação no campo da chamada medicina tropical, mas foi igualmente orientada para legitimar uma agenda de pesquisa e uma forma de intervenção no mundo a partir da ideia de saneamento.

\section{Quantificação e análise comparada das séries de fotografias}

As séries de registros fotográficos realizadas pelas expedições do Instituto Oswaldo Cruz no triênio 1911-1913 são conjuntos orgânicos de documentos, ou seja, foram produzidos como conjuntos, em um determinado tempo, por agentes específicos, em razão de uma atividade ou função. Assim, cada um dos conjuntos pode, a princípio, ser tratado como uma unidade, como totalidade que preexiste ao processo mesmo de pesquisa. São ao todo 929 registros fotográficos identificados, que integram o acervo fotográfico da Casa de Oswaldo Cruz, da Fundação Oswaldo Cruz. ${ }^{6}$

No Quadro 1 são apresentadas as expedições, indicando-se seus líderes, seu período, as instituições realizadoras e promotoras, os totais de registros realizados e, quando for o caso, publicados e as ocorrências temáticas verificadas em cada uma das situações. Incluemse também dados referentes às imagens de doentes, lesões, flora e fauna identificadas como pertencentes a cada um dos conjuntos.

A definição dos temas a serem trabalhados foi feita a partir da observação atenta das séries em seu conjunto. Buscou-se abarcar todo o universo temático, evitando, contudo, um número excessivo de temas, que poderia resultar em pulverização das ocorrências e perda de significação quantitativa das frequências percentuais.

Os temas estabelecidos foram definidos da seguinte forma: (1) Autorretratos, reunindo os registros sobre a própria expedição, seus componentes e atividades específicas; (2) Transportes e Outros Serviços Públicos, englobando atividades e meios, ainda que rústicos, nas áreas de transporte, abastecimento, administração pública, segurança etc; (3) Paisagens Urbanas, envolvendo as tomadas panorâmicas ou em plano aberto de cidades, vilas e povoados; (4) Cenas de Rua, Cotidiano Urbano, reunindo os registros realizados no interior dos núcleos populacionais, quando se observa a presença de transeuntes, retratos de 
habitantes dos núcleos, suas habitações e interiores; (5) Paisagens Rurais, Fluviais e Litorâneas, englobando as tomadas panorâmicas e em plano aberto de áreas rurais e ribeirinhas e, raramente, litorâneas; (6) Populações Rurais, abarcando retratos individuais e de grupos de habitantes das zonas rurais e suas habitações; (7) Trabalho Rural, reunindo os registros de populações rurais em atividades de produção; e (8) Técnicas, reunindo os registros que além da atividade de trabalho, apresentam uma preocupação com os processos de produção

QUADRO 1

Expedições do Instituto Oswaldo Cruz - 1911/1913

Quadro Geral de Registros Realizados e Publicados

\begin{tabular}{|c|c|c|c|c|c|c|}
\hline $\begin{array}{l}\text { Expedição - } \\
\text { líderes e } \\
\text { instituições }\end{array}$ & $\begin{array}{l}\text { Registros } \\
\text { realizados }\end{array}$ & $\begin{array}{c}\text { Registros } \\
\text { publicados }\end{array}$ & $\begin{array}{c}\text { Ocorrências } \\
\text { temáticas } \\
\text { realizadas }\end{array}$ & $\begin{array}{l}\text { Ocorrências } \\
\text { temáticas } \\
\text { publicadas }\end{array}$ & $\begin{array}{l}\text { Registros de } \\
\text { doentes, } \\
\text { flora e } \\
\text { fauna } \\
\text { identificados }\end{array}$ & $\begin{array}{c}\text { Total de } \\
\text { registros } \\
\text { realizados }\end{array}$ \\
\hline $\begin{array}{l}\text { Expedição aos } \\
\text { Vales do São } \\
\text { Francisco e } \\
\text { do Tocantins - } \\
\text { Astrogildo } \\
\text { Machado e } \\
\text { Antonio } \\
\text { Martins - } \\
\text { IOC/EFCB }\end{array}$ & 128 & - & 152 & - & 29 & 157 \\
\hline $\begin{array}{l}\text { Expedição pelo } \\
\text { Rio São Francisco } \\
\text { e seus Afluentes - } \\
\text { Adolpho Lutz e } \\
\text { Astrogldo } \\
\text { Machado - } \\
\text { IOC/IOCS }\end{array}$ & 112 & 69 & 113 & 63 & 13 & 125 \\
\hline $\begin{array}{l}\text { Expedição ao } \\
\text { Nordeste e ao } \\
\text { Centro Oeste - } \\
\text { Belisário Pena } \\
\text { e Arthur Neiva - } \\
\text { IOC/IOCS }\end{array}$ & 156 & 116 & 146 & 48 & 44 & 200 \\
\hline $\begin{array}{l}\text { Expedição ao } \\
\text { Ceará e ao } \\
\text { Norte do Piauí - } \\
\text { João Pedro de } \\
\text { Albuquerque e } \\
\text { José Gomes de } \\
\text { Faria - IOC/IOCS }\end{array}$ & 82 & - & 92 & - & 9 & 91 \\
\hline $\begin{array}{l}\text { Expedição ao } \\
\text { Amazonas e ao } \\
\text { Acre - Carlos Chag } \\
\text { Pacheco Leão e } \\
\text { João Pedro de } \\
\text { Albuquerque - } \\
\text { IOC/SDB }\end{array}$ & 342 & - & 411 & - & 14 & 356 \\
\hline Totais & 820 & 185 & 914 & 111 & 109 & 929 \\
\hline
\end{tabular}


em si, seus instrumentos e instalações, assim como os instrumentos de trabalho registrados isoladamente. Definiram-se ainda os temas Doentes, Flora e Fauna, que, por razões apresentadas adiante, foram considerados apenas em relação às imagens publicadas e tratados em separado.

A variedade temática está presente nessas imagens fotográficas, que apresentam, por vezes, um, dois, ou mesmo três temas numa única imagem. Procurou-se - reconhecendo-se os limites da nossa pretensão - quantificar apenas aqueles temas que parecem 'emergir' do registro realizado, evitando-se uma atribuição de temas essencialmente determinada pela nossa subjetividade na condição de observadores. Dessa maneira as frequências percentuais apresentadas nos Quadros dizem respeito ao total de ocorrências e não ao total de registros.

Duas expedições incluíram, nos relatórios publicados, conjuntos numericamente expressivos de imagens fotográficas. Tendo em vista a comparação do que foi produzido com o que foi publicado, as fotografias presentes nos relatórios foram submetidas aos mesmos procedimentos de quantificação. ${ }^{7}$

Nos Quadros 2 a 6 são apresentadas as informações referentes a cada expedição, indicando-se o numero de ocorrências temáticas realizadas e, quando for o caso, publicadas, assim como a sua distribuição percentual segundo cada um dos temas. No Quadro 7 apresenta-se a distribuição das imagens relativas a doentes, lesões, flora e fauna publicadas nos dois relatórios ilustrados disponíveis.

QUADRO 2

Machado e Martins - IOC/EFCB

São Francisco e Tocantins - 1911/1912

Registros realizados

\begin{tabular}{lcr}
\hline Temas & Ocorrências temáticas & \% \\
\hline Autorretratos & 23 & 15,1 \\
Transportes e Serviços Públicos & 15 & 9,8 \\
Paisagens Urbanas Vilas e Povoados & 18 & 11,8 \\
Cenas de Rua, Cotidiano Urbano & 33 & 21,7 \\
Paisagens Rurais e Fluviais & 45 & 29,7 \\
Populações Rurais, Condições de Vida & 7 & 4,6 \\
Trabalho Rural & 10 & 6,6 \\
Técnicas & 1 & 0,7 \\
\hline Totais & $\mathbf{1 5 2}$ & $\mathbf{1 0 0}$ \\
\hline
\end{tabular}

QUADRO 3

Chagas, Pacheco Leão e Albuquerque - IOC/SDB

Amazonas e Acre - 1912/1913

Registros realizados

\begin{tabular}{lrr}
\hline Temas & Ocorrências temáticas & $\%$ \\
\hline Autorretratos & 8 & 1,9 \\
Transportes e Serviços Públicos & 102 & 24,8 \\
Paisagens Urbanas Vilas e Povoados & 114 & 27,7 \\
Cenas de Rua, Cotidiano Urbano & 35 & 8,5 \\
Paisagens Rurais e Fluviais & 117 & 28,5 \\
Populações Rurais, Condições de Vida & 29 & 7,1 \\
Trabalho Rural & 4 & 1 \\
Técnicas & 2 & 0,5 \\
\hline Totais & $\mathbf{4 1 1}$ & $\mathbf{1 0 0}$ \\
\hline
\end{tabular}


QUADRO 4

Albuquerque e Gomes de Faria - IOC/IOCS

Ceará e Norte do Piauí - 1912

Registros realizados

\begin{tabular}{lcc}
\hline Temas & Ocorrências temáticas & $\%$ \\
\hline Autorretratos & 5 & 5,4 \\
Transportes e Serviços Públicos & 11 & 12 \\
Paisagens Urbanas Vilas e Povoados & 15 & 16,3 \\
Cenas de Rua, Cotidiano Urbano & 4 & 4,3 \\
Paisagens Rurais e Fluviais & 43 & 46,7 \\
Populações Rurais, Condições de Vida & 7 & 7,6 \\
Trabalho Rural & 3 & 3,3 \\
Técnicas & 4 & 4,4 \\
\hline Totais & $\mathbf{9 2}$ & $\mathbf{1 0 0}$ \\
\hline
\end{tabular}

QUADRO 5

Lutz e Machado - 1912 - IOC/IOCS

São Francisco e seus Afluentes

Registros realizados

\begin{tabular}{lcc}
\hline Temas & Ocorrências temáticas & $\%$ \\
\hline Autorretratos & 0 & 0 \\
Transportes e Serviços Públicos & 14 & 12,4 \\
Paisagens Urbanas Vilas e Povoados & 26 & 23 \\
Cenas de Rua, Cotidiano Urbano & 5 & 4,4 \\
Paisagens Rurais e Fluviais & 59 & 52,2 \\
Populações Rurais, Condições de Vida & 4 & 3,6 \\
Trabalho Rural & 3 & 2,6 \\
Técnicas & 2 & 1,8 \\
\hline Totais & $\mathbf{1 1 3}$ & $\mathbf{1 0 0}$ \\
\hline
\end{tabular}

Registros publicados

\begin{tabular}{lcc}
\hline Temas & Ocorrências temáticas & $\%$ \\
\hline Autorretratos & 0 & 0 \\
Transportes e Serviços Públicos & 9 & 14,3 \\
Paisagens Urbanas Vilas e Povoados & 10 & 15,9 \\
Cenas de Rua, Cotidiano Urbano & 3 & 4,8 \\
Paisagens Rurais e Fluviais & 36 & 57 \\
Populações Rurais, Condições de Vida & 3 & 4,8 \\
Trabalho Rural & 1 & 1,6 \\
Técnicas & 1 & 1,6 \\
\hline Totais & $\mathbf{6 3}$ & $\mathbf{1 0 0}$ \\
\hline
\end{tabular}

Por se tratar de análise quantitativa, é preciso que a integralidade do conjunto seja aferida mediante uma crítica externa que contemple a análise do conjunto como totalidade. A identificação de ausências numericamente expressivas ou dúvidas quanto a sua autoria ou circunstância de produção - quanto ao seu caráter orgânico, portanto - devem ser cuidadosamente avaliadas. Fontes documentais históricas são vestígios do passado e podem resultar de processos que incluíram a sua destruição ou dispersão parcial ao longo do tempo. Em outras circunstâncias, muitas vezes chegam ao nosso alcance como resultado de trabalhos de documentação, realizados em arquivos e em centros de documentação, que quase sempre implicam em processos de reconstituição de conjuntos. 
QUADRO 6

Neiva e Penna - IOC/ IOCS

Nordeste e Centro-Oeste - 1912

Registros realizados

\begin{tabular}{lcc}
\hline Temas & Ocorrências temáticas & \% \\
\hline Autorretratos & 18 & 12,3 \\
Transportes e Serviços Públicos & 24 & 16,5 \\
Paisagens Urbanas Vilas e Povoados & 23 & 15,8 \\
Cenas de Rua, Cotidiano Urbano & 3 & 2 \\
Paisagens Rurais e Fluviais & 35 & 24 \\
Populações Rurais, Condições de Vida & 25 & 17,1 \\
Trabalho Rural & 11 & 7,5 \\
Técnicas & 7 & 4,8 \\
\hline Totais & $\mathbf{1 4 6}$ & $\mathbf{1 0 0}$ \\
\hline
\end{tabular}

Registros publicados

\begin{tabular}{lrr}
\hline Temas & Ocorrências Temáticas & $\%$ \\
\hline Autorretratos & 4 & 4,7 \\
Transporte e Serviços Públicos & 15 & 17,7 \\
Paisagens Urbanas Vilas e Povoados & 17 & 20 \\
Cenas de Rua, Cotidiano Urbano & 1 & 1,2 \\
Paisagens Rurais e Fluviais & 16 & 18,8 \\
Populações Rurais, Condições de Vida & 16 & 18,8 \\
Trabalho Rural & 8 & 9,4 \\
Técnicas & 8 & 9,4 \\
\hline Totais & $\mathbf{8 5}$ & $\mathbf{1 0 0}$ \\
\hline
\end{tabular}

QUADRO 7

Lutz e Machado - 1912 / Neiva e Penna - 1912

Registros publicados

Comparação entre percentuais para registros sobre doentes, flora e fauna publicados

\begin{tabular}{lcc}
\hline Temas & Lutz e Machado - 1912 & Neiva e Penna - 1912 \\
\hline Doentes e Lesões & 0 & 20,3 \\
Flora & 11,5 & 17,7 \\
Fauna & 2,8 & 2,5 \\
\hline
\end{tabular}

Um primeiro aspecto a ser considerado consiste no fato de, em todas as expedições, terem sido identificadas imagens que reproduzem, em plano fechado ou em detalhe, aspectos da fauna, da flora e de doentes com sintomas visíveis das doenças encontradas nas regiões percorridas. No entanto boa parte dos negativos e das cópias dessas imagens encontravase dispersa pelas séries, o que tornou difícil, na reconstituição arquivística desses conjuntos, a identificação de locais e ocasiões em que essas fotografias foram produzidas - exceto quando tais informações estão disponíveis nos suportes ou em fontes textuais, o que nem sempre ocorre. Esse fato implicou na impossibilidade de trabalhar quantitativamente os registros de doentes, da flora e da fauna em conjunto com os demais temas, sob o risco de, dada a sua dispersão, comprometer a qualidade de inferências a partir da frequência relativa entre os temas das imagens. Assim, uma possibilidade de análise ficou prejudicada, a de comparar o número de registros produzidos sobre os temas do ambiente e condições sociais com aqueles realizados em plano fechado, cujo foco concentra-se no detalhe de espécimes 
da flora ou fauna e de manifestações morfológicas de doenças. Comparações dessa ordem somente foram possíveis considerando-se as imagens publicadas nos relatórios, uma vez que, nesse caso, trata-se de um conjunto de imagens sabidamente íntegro e que corresponde a uma intenção documentária/discursiva legitimada pelos pesquisadores autores. Por essa razão, ainda que indicadas no Quadro 1, as imagens com essas características foram isoladas da análise comparativa das imagens. Todavia, como se verá, é proposta uma comparação entre as imagens publicadas, no Quadro 7.

Entre as cinco expedições, a que percorreu os Vales do São Francisco e do Tocantins, em 1911 e em 1912, distingue-se das demais por ser a única que não teve os seus negativos guardados ou preservados pelo Instituto Oswaldo Cruz. É distinta, também, porque as fontes textuais disponíveis sugerem que foi de fato liderada pelo seu engenheiro chefe, a serviço da EFCB, cabendo a Astrogildo Machado e a Antonio Martins um papel complementar, de apoio aos trabalhos de definição do traçado de uma ferrovia. Esses elementos sugerem que o fotógrafo e seu auxiliar podem ter realizado seu trabalho sob orientação da turma de engenharia e não sob a dos especialistas médicos que acompanhavam a empreitada.

Um indício quantitativo e uma observação qualitativa reforçam essa percepção. Astrogildo Machado foi o único pesquisador presente em duas expedições: a que estamos comentando e a expedição que, em 1912, na companhia de Adolpho Lutz, dirigiu-se ao São Francisco e aos seus afluentes. Entretanto, mesmo que precários, os dados quantitativos sobre as imagens indicam um perfil documentário radicalmente distinto entre as duas expedições, especialmente quanto aos temas Autorretratos e Cenas de Rua e Cotidiano Urbano. Estas últimas, produzidas na expedição aos rios São Francisco e Tocantins, são revestidas de olhar e estética acentuadamente antropológicos, não observados em nenhuma outra (Stepan, 1994). De qualquer modo, essas particularidades, em primeiro lugar, implicam na impossibilidade de estabelecer correlação entre as cópias fotográficas que hoje fazem parte do acervo da Casa de Oswaldo Cruz e a totalidade do que foi efetivamente produzido durante a expedição. Em segundo lugar, resultam em dificuldade de analisar tais como expressão de uma intenção documentária do pesquisador e do farmacêutico do Instituto. Assim, essas expedições e seus registros foram isolados, para efeito de análise comparada mais completa.

No que se refere às demais expedições, a presença no acervo dos negativos, combinada, quando possível, às séries de imagens incluídas nos relatórios publicados indica que os conjuntos preservados podem ser considerados, com relativa segurança, como expressão bastante próxima daquilo que foi produzido, a não ser pelas restrições aos registros sobre doentes, fauna e flora, já comentadas.

Considerando também como possível exceção a expedição da $\mathrm{EFCB}$, os fotógrafos das demais expedições dispunham dos mesmos meios tecnológicos para a obtenção dos registros. ${ }^{8}$ As câmeras fotográficas eram de grande formato e utilizaram-se negativos no tamanho $13 \times 18 \mathrm{vm}$, sensibilizados com o uso de gelatina seca, técnica generalizada desde a década de 1880. Sabe-se também que pelo menos a expedição de Neiva e Penna utilizou recursos de telefotografia, ainda que em raras oportunidades. Esses recursos técnicos conformavam as possibilidades de registro então disponíveis. Por outro lado, seu alto custo e transporte especialmente trabalhoso são por si indicativos da importância atribuída 
à atividade documentária nas expedições. Sua presença não tinha nada de fortuita; ao contrário, era parte relevante do aparato tecnocientífico mobilizado em cada um daqueles empreendimentos.

Essas considerações acerca da técnica fotográfica têm importância para uma análise comparada dos discursos fotográficos das expedições. Se os aparatos técnicos são elementos constituintes da imagem, as quatro expedições analisadas parecem ter sido equipadas com os mesmos recursos técnicos para a produção dos registros fotográficos. Trata-se, assim, de elemento que se configura, nesses casos, de forma homogênea: para efeitos de uma quantificação, uma variável que se manifesta como constante.

Além de uma tecnologia comum, é possível identificar outros importantes elementos constitutivos da imagem fotográfica comuns a três dessas expedições. As expedições lideradas por Albuquerque e Gomes de Faria, Lutz e Machado e Neiva e Penna (Quadros 4, 5 e 6) realizaram-se sob os auspícios do mesmo organismo federal, a Inspetoria de Obras contra as Secas. Todas elas percorreram regiões do sertão nordestino e do Centro-Oeste durante o período da seca. Em termos gerais, não é de se supor que suas populações vivessem situações radicalmente díspares quanto às condições de vida, e ainda que variassem em incidência, as entidades mórbidas deveriam assemelhar-se nos três percursos. Portanto parece razoável trabalhar com a ideia de que a realidade circundante tenha proporcionado visualidades similares a cada um de seus líderes.

Para efeito do presente exercício, que pretende uma abordagem quantitativa dos elementos conformadores da imagem fotográfica, a Expedição de Chagas, Pacheco Leão, e João Pedro de Albuquerque também será isolada da análise. Embora especialmente relevante e bem documentada, ela foi realizada sob os auspícios da Superintendência de Defesa da Borracha e informada pela problemática da crise de preços desse produto, assim como pelo ambiente geográfico e socioeconômico específico do Amazonas e seus principais afluentes a partir de Manaus. Assim, suas imagens foram produzidas a partir de elementos distintos das demais, tornando uma comparação quantitativa mais problemática, nos termos aqui propostos.

Já nos registros fotográficos das três expedições que se dirigiram ao Nordeste e CentroOeste sob auspícios da Inspetoria de Obras Contra as Secas - tendo em mente os elementos determinantes da imagem fotográfica aqui apresentados -, encontramos: (1) um ambiente e visualidades semelhantes; (2) as mesmas instituições envolvidas, sugerindo temas similares; e (3) os mesmos aparatos técnicos para a realização dos registros. Esses elementos comuns não foram, entretanto, capazes de imprimir um perfil documentário único para as três expedições, ao mesmo tempo que apenas os 'olhares' que fotografam permanecem de fato como variáveis.

De fato, no tema Autorretratos ocorre uma variação de ocorrências entre zero (Lutz e Machado) e 12,3\% (Neiva e Penna); em Paisagens Rurais e Fluviais o intervalo observável entre as ocorrências temáticas é de $24 \%$ (Neiva e Penna) a 52,2\% (Lutz e Machado), uma diferença equivalente a 42 ocorrências entre 146 possíveis. Combinando-se os temas Populações Rurais, Trabalho Rural e Técnicas, o comportamento das três expedições é 8,2\% (Lutz e Machado); 15,3\% (Albuquerque e Gomes de Faria) e 29,4\% (Neiva e Penna). Portanto 
as diferenças na produção de registros entre as expedições, em cinco dos oito temas examinados, é bastante expressiva, variando entre $12,3 \%$ e $28,2 \%$.

Como já observamos, em situações como as que estamos examinando o olhar que fotografa é potencialmente combinado, pois articula olhares do fotógrafo, dos pesquisadores e das instituições. Os números examinados acima indicam que não é o ponto de vista das instituições que prevalece, pelo menos de forma absoluta.

Se compararmos o material produzido pelas expedições com aquele publicado (Quadros 5 e 6), podemos extrair novas inferências. Os dados indicam que as distribuições das frequências temáticas pelos temas são similares nas duas situações. As variações mais altas ocorrem quanto ao tema Autorretratos $(7,6 \%)$ na expedição Neiva e Penna e Paisagens Urbanas $(7,2 \%)$ na expedição Lutz e Machado. As demais diferenças se mantêm entre 0,3 e $5,1 \%$. Na viagem de Lutz e Machado, em oito temas, seis apresentam variações inferiores a $2 \%$, e a diferença em Paisagens Urbanas parece significar uma tentativa de acentuar uma predominância de Paisagens Rurais e Fluviais, já presente nas imagens produzidas. No caso da Expedição de Neiva e Penna, encontramos variações inferiores a 2\% na metade dos temas, e a economia obtida em Autorretratos - considerados, talvez, um excesso de imagens autorreferidas - e Paisagens Rurais e Fluviais é utilizada para acentuar o peso relativo das ocorrências em Paisagens Urbanas, Populações Rurais e Condições de Vida, Trabalho Rural e Técnicas. Novamente uma particularidade do perfil documentário da expedição parece ser aqui acentuada na publicação dos seus resultados.

Se tivermos em mente que os relatórios e respectivas imagens foram publicadas nas Memórias do Instituto Oswaldo Cruz, publicação voltada para a comunicação científica, portanto voltada para os pares, é de supor que as imagens publicadas reflitam exatamente o que foi considerado relevante pelos cientistas que chefiaram as expedições. Em outros termos: as imagens publicadas são aquelas que conferem sentido à ação documentária, segundo a perspectiva de seus pesquisadores-chefes, estando, ainda, em acordo com as suas respectivas institucionalidades. E, como observamos, o perfil da documentação fotográfica produzida é significativamente próxima daquilo que foi publicado, de modo que podemos concluir que a realização dos registros obedeceu, em larga medida, os critérios de relevância determinados pelos pesquisadores. Assim, na combinação de possíveis olhares conformadores das imagens fotográficas - entre aqueles dos fotógrafos, dos pesquisadores, das instituições -, nossa análise indica ter prevalecido a perspectiva orientada por motivações e interesses dos pesquisadores líderes de cada empreitada, assim como seus modos particulares de vivenciar a sua própria inserção institucional.

\section{A expedição Neiva e Penna: imagens pelo saneamento}

A expedição que percorreu os sertões da Bahia, de Pernambuco, do Piauí e de Goiás até atingir o interior paulista é aquela que mais diretamente se associa ao movimento pelo saneamento dos sertões que, na segunda metade da década de 1910, ganharia força na opinião pública, especialmente na capital do país, no qual Neiva e Penna, especialmente este último, exerceriam papel decisivo. 
Em 1917, através de uma série de artigos publicados no jornal O Estado de São Paulo, mais tarde reunidos em livro sob título Saneamento do Brasil (Penna, 1918), Belisário Penna iniciou uma militância ininterrupta que incluiu a fundação da Liga Pró-Saneamento do Brasil (1918) e um sem-número de viagens para palestras e conferências. Na empreitada que então iniciava, o próprio relatório da expedição de 1912 e suas imagens se tornariam, a um só tempo, peça de propaganda e evidência científica de um diagnóstico acerca de uma realidade que pretendia denunciar e transformar.

O relatório da viagem científica de Arthur Neiva e Belisário Penna ao norte da Bahia, sudoeste de Pernambuco, sul do Piauí e norte a sul de Goiás, publicado nas Memórias do Instituto Oswaldo Cruz em 1916, encontra-se organizado em duas partes. Na primeira parte, encontram-se a descrição e sistematização dos principais temas observados pelos pesquisadores durante a viagem: clima, vegetação (estudos detalhados sobre a flora incluindo a identificação de espécies, com referências a textos anteriores de naturalistas brasileiros e estrangeiros); processo de desertificação do interior do país (relacionado à diminuição das águas e ao desflorestamento); observações científicas sobre plantas venenosas, protozoários, vermes, insetos e sobre as principais doenças encontradas, tais como doença de Chagas, febre amarela, impaludismo, esquistossomose, tuberculose e disfagia espasmódica. Contém, ainda, observações sobre terapêutica popular e notas gerais em que os autores desenvolvem, em narrativa mais fluida, suas observações e análises sobre as condições de vida e trabalho das populações das regiões percorridas. A segunda parte intitula-se "Itinerário (parte descritiva)", diário de viagem propriamente dito, com observações dos cientistas desde a saída do Rio de Janeiro, em março de 1912, até o retorno à mesma cidade, em outubro do mesmo ano.

Seguem então as fotografias, num total de 116 imagens, distribuídas em 28 páginas. Em geral, elas estão compostas, nas páginas, em conjuntos de quatro imagens retangulares, a maioria medindo entre $6 \times 8 \mathrm{~cm}$. Constam ainda, três fotografias circulares, uma panorâmica e duas imagens identificadas como telofotografias, o que pode significar não um simples erro ortográfico, mas uma terminologia ainda em gestação e não consolidada, referida a uma tecnologia ainda pouco usual: as teleobjetivas, que 'aproximam' os objetos à distância.

Cada fotografia é acompanhada de legenda própria, a maioria delas não apenas com identificação do tema retratado, como também com observações científicas, explicações e comentários sobre as condições de vida das localidades. ${ }^{9}$

A sequência de imagens do Relatório inicia com uma apresentação de diversas espécies de plantas, árvores e arbustos (macambiras, umburana de espinho, cabeça de frade; gameleira, marmeleiro, baraúna, jatobá, umbuzeiro, faveleira, tamburil, joazeiro etc.), identificadas, quase sempre, pelo nome popular e pelo nome científico. Em seguida apresentase um registro sobre a própria expedição (foto de acampamento) e outra sequência de fotografias mesclando paisagens rurais e urbanas (entendidas aqui como aspectos de cidades, vilas e povoados), vistas, tipos variados de moradias e construções. Constam também imagens que informam sobre meios e serviços de transporte existentes nas localidades (embarcações, locomotivas, ferrovias, animais etc.) e que, ao mesmo tempo, enriquecem o painel das paisagens retratadas. Destaca-se, nessa parte, a imagem de uma locomotiva 
parada por falta de combustível, na Estrada de Ferro São Francisco; de acordo com a legenda, essa era uma cena comum na época. Tipos rurais também são apresentados, a exemplo do "vaqueiro da caatinga", encontrado em Pernambuco.

Surgem então outros registros sobre a dinâmica da expedição, com imagens da travessia pelas cabeceiras do rio Preto, na Bahia. Em seguida, inúmeras fotografias que contemplam igualmente a população, as moradias rurais e as atividades, técnicas e processos relacionados ao trabalho (engenhos de farinha e de cana-de-açúcar, engenho de tear etc.). A questão do abastecimento e da distribuição de água também está representada.

A essa altura vale introduzir uma nova comparação, agora entre as imagens de Doentes e Flora e Fauna incluídas nos únicos relatórios ilustrados disponíveis (Quadro 7), os das expedições de Lutz e Machado e de Neiva e Penna. Essas imagens podem ser compreendidas como parte de conjuntos documentais sabidamente íntegros. Ambas têm percentuais bastante semelhantes quanto às imagens da Flora (11,5\% e $17,7 \%$, respectivamente) e Fauna (2,8\% e 2,5\%). Quanto a Doentes e Lesões, todavia, a diferença é absoluta e expressiva. Enquanto Lutz e Machado não publicaram nenhuma imagem, Neiva e Penna incluíram uma fotografia sobre o tema a cada cinco imagens que ilustraram o relatório $(20,3 \%)$. São 25 fotografias de doentes, apresentados sob as mais variadas formas: individuais, em grupo, corpo inteiro, busto, três quartos de corpo etc. Pela força de suas imagens, esse segmento constitui um conjunto impressionante.

Além de ter como objetivo reproduzir a sequência de apresentação das imagens do relatório, a descrição dos assuntos/temas retratados (elementos de conteúdo) nas imagens do Relatório buscou evidenciar a existência de uma narrativa visual implícita na sua seleção, ordenação e apresentação. Essa narrativa, encadeando as imagens entre si, se inicia com uma espécie de apresentação do espaço físico, geográfico e ambiental - atuando no sentido de contextualizar o leitor espacialmente - e perpassa as condições de vida e trabalho das populações dessas regiões (moradias, transportes, atividades econômicas) encerrando-se com o 'clímax' das denúncias feitas a partir dessa expedição e do relatório: a imagem do Brasil 'doente'.

No percurso dessa trajetória, a narrativa vai se construindo paulatinamente e resulta num inventário visual das condições geográficas, ambientais, sociais e econômicas da população das regiões percorridas. Esse 'texto visual', inclusive, pode constituir um 'segundo' texto, paralelo, quase autônomo. As legendas - que estabelecem a relação entre as imagens e o argumento desenvolvido no texto - reforçam fortemente tal caráter, uma vez que, além de informativas, contêm observações e comentários. Quanto mais completa e rica uma legenda, maior a autonomia da imagem com relação ao texto.

A análise sobre esse material permite identificar diferentes usos da imagem fotográfica no contexto da expedição Neiva e Penna e seus desdobramentos, perpassando os circuitos de produção, consumo e leitura das fotografias. Em primeiro lugar, a utilização documentária, um dos usos mais disseminados da imagem fotográfica, sobretudo em ambientes institucionais. Diz respeito à construção de seu valor como evidência e prova (Mello, 2007, p.57-65; Mello, Lacerda, 2005, p.179-198), associada à emergência de novas instituições e novas práticas de observação e acumulação de registros, por parte do Estado e de um conjunto de instituições de tipo disciplinar, como a polícia, as prisões, os asilos, os 
hospitais, os departamentos de saúde pública, as escolas e o próprio sistema moderno de fábricas (Tagg, 1993).

Essa época, que testemunhou a emergência e o reconhecimento oficial da fotografia instrumental, é a mesma que inaugura a disseminação de seu uso na área científica. A fotografia é alçada à categoria de instrumento de registro, verificação, prova, e nas diversas dinâmicas dos trabalhos em laboratório, assim como nas áreas da saúde pública e nos discursos médicos, passa a ser parte integrante dos procedimentos científicos. Nesse sentido, é possível verificar na utilização de imagens no relatório da expedição Neiva e Penna, tanto o caráter documental dessas fotos quanto o valor de prova a elas atribuído, confirmando observações e legitimando discursos.

Entretanto, apesar da 'quase autonomia' da narrativa visual contida nas imagens do relatório, julgamos fundamental retomar a noção de intertextualidade no trabalho com fontes históricas, apontada anteriormente. Nessa perspectiva, o cotejamento e a confrontação entre os diversos textos concorrentes, numa mesma época, permitem uma compreensão mais acurada dos contextos de produção e circulação dessas imagens. No nosso caso, o estabelecimento de pontos de interseção entre as imagens e o texto do relatório é bastante interessante, pois nos permite a observação do processo pelo qual as imagens fotográficas não apenas confirmam as assertivas do texto, como também reproduzem a argumentação e o discurso científico, com o caráter de comprovação, de prova do que está sendo dito. $\mathrm{E}$ esse é um caminho de mão dupla: a leitura e interpretação do texto são bastante enriquecidas a partir da 'leitura' das imagens.

Outro aspecto a ser observado é que somente a partir da leitura de outros textos contemporâneos ao relatório pudemos identificar o peso atribuído a diversos elementos, tanto no texto quanto nas imagens. Para ser interpretada como texto (suporte de relações sociais), a imagem demanda o conhecimento de outros textos que a precedem ou que com ela concorrem, na produção da textualidade de uma época (Mauad, 2005, p.140). Na nossa avaliação, o exemplo mais emblemático disso é o tratamento e a ênfase atribuídos à doença de Chagas no relatório. Como observa Lima (2003, p.196), fica claro, no relatório da expedição Neiva e Penna, que um dos objetivos da viagem fora encontrar evidências que corroborassem a importância epidemiológica da doença de Chagas. Isso pode ser observado tanto pelo número de páginas (dez) dedicadas à doença, mais do que a qualquer outra enfermidade, quanto pelo registro minucioso das diversas designações populares para o inseto responsável pela transmissão da doença: cascudo, borrachudo, percevejo, percevejão, percevejo grandeiro, chupão e barbeiro, entre outras (Neiva, Penna, 1984, p.100).

Descoberta em 1909, a doença de Chagas teve grande repercussão nos meios científicos nacionais e estrangeiros, e fez com que Chagas fosse agraciado com importantes distinções acadêmicas e ocupasse cargos administrativos de grande projeção no campo biomédico. Além disso, instituiu, no Instituto Oswaldo Cruz, uma ampla agenda de pesquisa em que seriam abordados os mais variados aspectos relacionados à nova doença, expressando a orientação firmada por Oswaldo Cruz de torná-la um tema estratégico para o fortalecimento e a consolidação institucional de Manguinhos (Kropf, Azevedo, Ferreira, 2000; Benchimol, Teixeira, 1993). 
Durante esse período, foram realizados estudos relacionados ao vetor, ao parasito e seus reservatórios, à patogenia, ao quadro clínico e ao diagnóstico da doença, e também se buscou demonstrar sua importância social como enfermidade que grassava em vastas regiões do país. Chagas defendeu, desde seus primeiros trabalhos, a tese de que a moléstia que descrobira atingia vastas regiões do país, assumindo uma condição endêmica a partir da qual se apresentava como importante problema social a ser enfrentado pelas autoridades de saúde pública (Kropf, Azevedo, Ferreira, 2000, p.351-352). ${ }^{10}$

Nesse contexto de estudos, investigações e questionamentos sobre a doença de Chagas foi realizada a expedição de Neiva e Penna, e isso provavelmente explica a ênfase com que a moléstia é abordada em texto e fotografias, no relatório. Ambos os elementos tanto denunciam as condições de adoecimento das populações interioranas, como promovem a pesquisa e o conhecimento produzidos pela medicina experimental, tal como a realizada no Instituto Oswaldo Cruz.

Assim é que, no universo de 25 fotografias de doentes, 17 referem-se direta ou indiretamente à doença de Chagas. A maioria apresenta portadores de bócio endêmico, considerado por Carlos Chagas, à época, uma das manifestações clínicas da tripanosso-míase americana - hipótese que recebeu muitas críticas e que posteriormente se revelou equivocada. ${ }^{11} \mathrm{~A}$ forma de apresentação dessas fotografias no relatório indica sua utilização como imagens médicas, no sentido estrito da expressão, já que focam na condição do enfermo em si. Alguns indivíduos doentes estão cuidadosamente colocados à frente de um fundo neutro, a fim de acentuar seu status de espécimes patológicas (Stepan, 1994, p.142). Nesses casos, as fotografias são tomadas de perto, quase como em close; os olhares dos retratados estão voltados para a câmara e o foco está nos detalhes, no caso o 'papo', o que denota a preocupação de uma descrição mais precisa daquela que, até então, era considerada uma das principais manifestações clínicas da doença. O papo tornava-se, de certa forma, o elemento visual definidor da doença de Chagas e suas imagens auxiliaram na construção do próprio objeto médico: o corpo doente como objeto de investigação do conhecimento médico e espécime exemplar de uma população a ser objeto de uma desejada intervenção da saúde pública.

Em outros casos, a ênfase é atribuída pela reunião de grupos de doentes acometidos pelos sintomas da doença. É o caso da fotografia de um grupo de mais de vinte "enfermos do sexo feminino e de todas as idades", tirada no Asilo São Francisco de Paula, na capital de Goiás, onde os doentes foram identificados como "representantes das várias modalidades clínicas da doença de Chagas". Nesse caso, a quantidade de pessoas doentes representadas, das mais variadas idades, confirmaria a grande incidência da doença nas vastas regiões do país.

Em geral, as imagens do relatório Neiva e Penna, apresentam um padrão comum de representação visual. São fotografias posadas, com enquadramentos tradicionais e consoantes com os recursos e padrões técnicos e estéticos fotográficos da época em que foram produzidas. Seja na representação da natureza, da paisagem natural, dos tipos humanos ou das condições de vida, as imagens obedecem a uma tradição de estética documental do final do século XIX, de composição harmônica dos elementos num 'quadro fotográfico' ainda bastante influenciado pela gravura e pela pintura acadêmica. 
Outro aspecto a observar é o fato de que, apesar da participação do fotógrafo José Teixeira na expedição, não se encontrar registros sobre o cotidiano dessa expressiva atividade profissional, ao que tudo indica bastante trabalhosa e dispendiosa em virtude dos recursos técnicos disponíveis na ocasião. Essa lacuna não nos permite avançar em determinados aspectos referentes à produção dos registros fotográficos, mas, de certa forma, reforça a ideia exposta anteriormente de que a lógica e o olhar que guiaram a produção das fotografias eram norteadas pelo 'modo de ver' dos médicos e pesquisadores do Instituto Oswaldo Cruz.

Por fim, ressaltamos as infinitas possibilidades de 'ressemantização' das imagens. Uma mesma imagem pode reciclar-se, assumir vários papéis, ganhar novos sentidos e produzir efeitos diversos. Por isso é fundamental a observação e recuperação dos contextos de produção, acumulação, circulação e consumo das imagens. No caso em questão, podemos mencionar os usos diferenciados das imagens produzidas pela expedição de Neiva e Penna. Como registros da viagem, em 1912, elas percorrem, exploram, mapeiam e registram o terreno. Fazem um inventário de seus objetos, investigam os lugares e as pessoas e inserem as doenças num quadro geográfico-ambiental e socioeconômico mais abrangente. A doença é representada como uma decorrência das condições naturais e sociais do Brasil.

Essas mesmas imagens foram publicizadas num circuito mais amplo, ao serem utilizadas em palestras, conferências, congressos médicos e em periódicos científicos. Para além da função de registro e comprovação, elas assumem outros papéis, passando a fazer parte do processo de divulgação e legitimação do conhecimento científico por meio de periódicos científicos e também de jornais e revistas populares. Posteriormente foram parte integrante dos debates travados em diversas instâncias - jornais, Academia Nacional de Medicina, congressos médicos etc. - sobre a doença de Chagas no Brasil. Nesse sentido, o texto visual é parte importante do processo de estabelecimento de uma agenda científica no campo da chamada medicina tropical.

Por fim, cabe ressaltar a importância dessas fotografias na constituição de um retrato do interior do Brasil no primeiro período republicano, quando as doenças foram identificadas como obstáculos à formação da nacionalidade. Principal tema do movimento por saneamento rural e reforma da saúde, que alcançou grande visibilidade em fins da década de 1910 (Lima, 2003, p.189), foi amplamente propagado na década de 1910 por representantes do movimento sanitarista, que, sobretudo a partir das expedições científicas do Instituto Oswaldo Cruz ao interior do país, chamavam a atenção para a gravidade dos prejuízos causados pelas endemias rurais ao desenvolvimento do país. Esses médicos e cientistas defendiam uma ampla reforma que, centralizando os serviços sanitários no âmbito do poder federal, conferisse prioridade ao saneamento rural e o implementasse de maneira sistemática. (Kropf, Azevedo, Ferreira, 2000, p.352). Os primeiros anos da República foram palco de expressivo movimento de valorização do sertão, ora como espaço a ser incorporado no esforço civilizatório das elites políticas do país, ora como referência da autenticidade nacional (Lima, 2003, p.191). ${ }^{12}$

A expedição de Neiva e Penna produziu o relatório de mais forte impacto científico e político. O retrato do Brasil então esboçado apontava a doença e o isolamento como principais problemas para o progresso das regiões. Esse texto e outros que a ele se seguiram, em torno da temática do saneamento do Brasil, formaram um importante quadro de 
referência para o debate sobre a identidade nacional (Lima, 2003, p.193). Assim, um discurso visual produzido a partir do olhar médico sanitário específico contribuiu para a instituição da saúde dos sertões, em tema da cultura e da política compartilhado por diferentes atores sociais. Com esse enquadramento, torna-se mais inteligível o legado documental da expedição e o discurso visual que fez publicar.

\section{NOTAS}

${ }^{1}$ Discutindo a 'fidedignidade' do registro fotográfico, Boris Kossoy (1980, p.37) já registra essa preocupação em distinguir a produção 'autônoma' dos fotógrafos daquelas realizadas por encomenda.

${ }^{2}$ Uma descrição completa das expedições e do seu contexto, assim como uma seleção representativa do material fotográfico por elas produzido está em Thielen et al., 1991. O item a seguir é parcialmente baseado nesse trabalho.

${ }^{3}$ A historiografia sobre as primeiras décadas do Instituto Oswaldo Cruz e a trajetória de Oswaldo Cruz é bastante expressiva. Ver, a esse respeito, Benchimol, 1990; Benchimol, Teixeira, 1993; e Stepan, 1976.

${ }^{4}$ Para o uso dessas categorias em associação com a de clínica médica, na compreensão do processo de introdução da medicina pasteuriana no Brasil no último quarto de século XIX, ver Benchimol, 1999.

${ }^{5}$ Para uma discussão sobre o tema da nação e dos sertões e sobre a importância desses empreendimentos expedicionários nas primeiras décadas republicanas, ver Lima, 1999, especialmente o capítulo 3.

${ }^{6}$ A análise quantitativa realizada nesta seção reproduz e introduz modificações, além de ampliar aquela levada a efeito por Eduardo Thielen e Ricardo Augusto dos Santos quando da elaboração de A ciência a caminho da roça (Thielen et al., 1991), o que implicou novas conclusões. A descrição em detalhes do seu desenvolvimento é feita aqui pela primeira vez.

${ }^{7}$ Os relatórios publicados são os de Adolpho Lutz e Astrogildo Machado (1915) e Belisário Penna e Arthur Neiva (1916), disponíveis em http://memorias.ioc.fiocruz.br. Um terceiro relatório, que não inclui, porém, fotografias é o relativo às condições médico-sanitárias do vale do Amazonas (Brasil, 1913).

${ }^{8}$ Uma sequência de imagens de um batelão vencendo uma corredeira sugere que João Stamato, na Expedição Machado e Martins, ao contrário de seus colegas das outras viagens, pode ter recorrido a filmes flexíveis de nitrato de celulose, já disponíveis em escala comercial desde 1902. O uso de placas de vidro teria dificultado significativamente a rápida operação de substituição das placas, que uma sequência desse tipo requeriria. Cabe observar também que não são conhecidos negativos em vidro dessa expedição.

${ }^{9}$ Devido à riqueza que trazem à leitura das imagens, as fotografias reproduzidas nesse trabalho são acompanhadas pelas legendas originais do relatório de viagem de Neiva e Penna (1916).

${ }^{10}$ Para uma análise do processo pelo qual a doença de Chagas foi estabelecida e reconhecida como fato científico e questão de saúde pública no Brasil, ver Kropf, 2006.

${ }^{11}$ Definido pela hipertrofia da glândula tireóide e caracterizado por aumento perceptível de volume na região do pescoço, o bócio - vulgarmente conhecido como papo - foi observado por Chagas em portadores da tripanossomíase americana, em diversas regiões de Minas Gerais onde se constatou a infestação das casas por barbeiros infectados. Tais circunstâncias o levaram a estabelecer uma relação direta entre as duas enfermidades.

12 Sobre o movimento sanitarista e a reforma dos serviços de saúde pública empreendidos durante a Primeira República, ver Castro-Santos, 1985; Labra, 1986; Lima, Hochman, 1996; e Hochman, 1998.

\section{REFERÊNCIAS}

BENCHIMOL, Jaime Larry.

Dos micróbios aos mosquitos: febre amarela e a revolução pasteuriana no Brasil. Rio de Janeiro: Editora Fiocruz. 1999.

BENCHIMOL, Jaime Larry.

Manguinhos do sonho à vida: a ciência na Belle
Époque. Rio de Janeiro: Casa de Oswaldo Cruz. 1990.

BENCHIMOL, Jaime Larry; TEIXEIRA, Luiz Antonio. Cobras, lagartos e outros bichos: uma história comparada dos institutos Oswaldo Cruz e Butantan. Rio de Janeiro: Editora UFRJ. 1993. 
BRASIL.

Ministério da Agricultura, Indústria e Comércio. Superintendência da Defesa da Borracha. Relatórios sobre as condições médico-sanitárias do vale do Amazonas. Rio de Janeiro: Revista dos Tribunais. 1913.

BRENNAN, Teresa; JAY, Martin (Ed.).

Vision context: reflexions and refractions. New York: Routledge. 1996.

CASTRO-SANTOS, Luiz A. de.

O pensamento sanitarista na Primeira Republica: uma ideologia de construção da nacionalidade. Dados - Revista de Ciências Sociais, Rio de Janeiro, v.28, n.2, p.193-210. 1985.

EDWARDS, Elizabeth (Ed.).

Anthropology and photography, 1860-1920.

New Haven: Yale University Press. 1997.

EDWARDS, Elizabeth; HART, Janice (Ed.). Photographs objects histories: on the materiality of images. London: Routledge. 2004.

HOCHMAN, Gilberto.

A era do saneamento. São Paulo: Anpocs; Hucitec. 1998.

JENKS, Chris (Ed.)

Visual culture. London: Routledge. 1995.

KNAUSS, Paulo.

O desafio de fazer História com imagens: arte e cultura visual. ArtCultura, Uberlândia, v.8, n.12, p.97-115. 2006.

KOSSOY, Boris.

A fotografia como fonte histórica: introdução à pesquisa e interpretação das imagens do passado. São Paulo: Museu da Industria Comercio e Tecnologia de São Paulo. 1980.

KROPF, Simone Petraglia.

Doença de Chagas, doença do Brasil: ciência, saúde e nação (1909-1962). Tese (Doutorado) Instituto de Ciências Humanas e Filosóficas, Universidade Federal Fluminense, Niterói. 2006.

KROPF, Simone Petraglia; AZEVEDO, Nara; FERREIRA, Luís Otávio.

Doença de Chagas: a construção de um fato científico e de um problema de saúde pública no Brasil. Ciência e Saúde Coletiva, Rio de Janeiro, v.5, n.2, p.347-365. 2000.

LABRA, Maria Eliana.

O movimento sanitarista dos anos 20: da conexão sanitária internacional à especialidade em saúde pública no Brasil'. Dissertação (Mestrado) - Escola Brasileira de Administração Pública, Fundação Getulio Vargas, Rio de Janeiro. 1985.
LACERDA, Aline Lopes de; MELLO, Maria

Teresa Villela Bandeira de.

Produzindo um imunizante: imagens da produção da vacina contra a febre amarela. História, Ciências, Saúde - Manguinhos, Rio de Janeiro, v.10, n.2, p.537-571. 2003.

LIMA, Nísia Trindade.

Viagem científica ao coração do Brasil: notas sobre o relatório da expedição de Arthur Neiva e Belisário Penna à Bahia, Pernambuco e Goiás (1912). Revista da Fundação do Homem Americano, Rio de janeiro, v.1, n.3, p.185-215. 2003.

LIMA, Nísia Trindade; HOCHMAN, Gilberto. Condenado pela ração, absolvido pela medicina: o Brasil descoberto pelo movimento sanitarista da Primeira República. In: Maio, Marcos Chor; Santos, Ricardo Ventura (Org.). Raça, ciência e sociedade. Rio de Janeiro: Fiocruz. p.23-40. 1996.

LUTZ, Adolpho; MACHADO, Astrogildo. Viagem pelo rio São Francisco e por alguns de seus afluentes entre Pirapora e Juazeiro. Memórias do Instituto Oswaldo Cruz, Rio de Janeiro, t.7, p.5-62. 1915.

MAUAD, Ana Maria.

Na mira do olhar: um exercício de análise da fotografia nas revistas ilustradas cariocas, na primeira metade do século XX. Anais do Museu Paulista, São Paulo, v.13, n.1, p.133-174. 2005.

MAUAD, Ana Maria.

Através da imagem: fotografia e história interfaces. Tempo, Niterói, v.1, n.2, p.73-98. 1996.

MELLO, Maria Teresa Villela Bandeira de. Imagens da memória: uma história visual da malária (1910-1960). Tese (Doutorado) Departamento de História, Universidade Federal Fluminense, Niterói. 2007.

MENESES, Ulpiano T. Bezerra de. Fontes visuais, cultura visual, história visual: balanço provisório, propostas cautelares. Revista Brasileira de História, São Paulo, n.45, v.23, p.11-36. 2003.

MENESES, Ulpiano T. Bezerra de.

A fotografia como documento: Robert Capa e o miliciano abatido na Espanha - sugestões para um estudo histórico. Tempo, Niterói, v.7, n. 13, p.131-151. 2002.

MIRZOEFF, Nicholas.

An introduction to visual culture. London: Routledge. 1999.

MITCHELL, William J. Thomas.

Picture theory: essays on verbal and visual 
representation. Chicago: The University of Chicago Press. 1994.

NEIVA, Artur; PENNA, Belisário.

Viagem científica pelo norte da Bahia, sudoeste de Pernambuco, sul do Piauí e de norte a sul de Goiás. Brasília: Academia Brasiliense de Letras. 1984.

NEIVA, Arthur; PENNA, Belisário. Expedição pelo norte da Bahia, sudoeste de Pernambuco, sul do Piauí e de norte a sul de Goiás. Memórias do Instituto Oswaldo Cruz, Rio de Janeiro, v.8, n.3, p.74-224. 1916.

PENNA, Belisário.

Saneamento do Brasil. Rio de Janeiro: Revista dos Tribunais. 1918.

SEVCENKO, Nicolau.

Literatura como missão: tensões sociais e criação cultural na Primeira Republica. São Paulo: Brasiliense. 1983.

STEPAN, Nancy.

Gênese e evolução da ciência brasileira. Rio de Janeiro: Artenova. 1976.

STEPAN, Nancy.

Portraits of a possible nation: photographing medicine in Brazil. Bulletin of the History of Medicine, Baltimore, n.68, p.136-49. 1994.

STURKEN, Marita; CARTWRIGHT, Lisa.

Practices of looking: an introduction to visual culture. Oxford: Oxford University Press. 2001.

TAGG, John.

The burden of representation: essays on photographies and histories. 2.ed. Minneapolis: University of Minnesota Press. 1995.

THIELEN, Eduardo Vilela et al.

A ciência a caminho da roça: imagens das expedições cientificas do Instituto Oswaldo Cruz em 1911 e 1912. Rio de Janeiro: Casa de Oswaldo Cruz. 1991.

TORRES, Alberto. Problema nacional brasileiro: introdução a um problema de organização nacional. São Paulo: Cia Editora Nacional. 1978.

WELLS, Liz (Ed.).

Photography: a critical introduction. London: Routledge. 1997. 
Maria Teresa Villela Bandeira de Mello, Fernando A. Pires-Alves

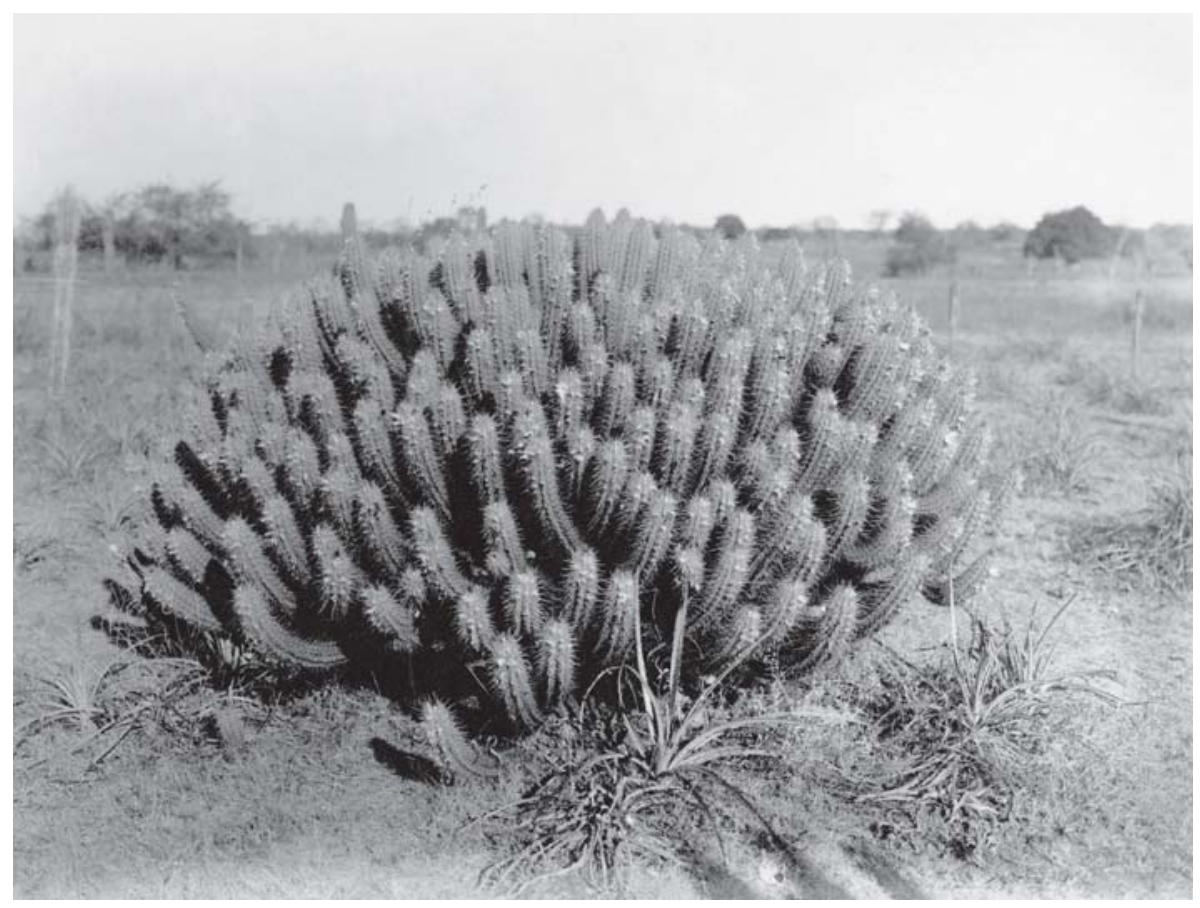

Figura 1: "Xique-xique denominação vulgar, designando provavelmente mais de uma espécie do gênero Pilocereus. Cactácea muito comum e que originou o nome de uma cidade baiana à margem do São Francisco. $\mathrm{O}$ vocabulário embora indígena não é tupi, mas pertencente a algumas das tribos de falar diferente e primitivos

dominadores daquelas paragens e cuja existência ainda nos é revelada por um ou outro vocábulo que resistiu à dominação lusitana e tupi dos conquistadores daquelas zonas. Fazenda da Cruz, Piauí. 1912". (Neiva, Penna, 1916, estampa 6; arquivo Belisário Penna, Casa de Oswaldo Cruz/Fiocruz)

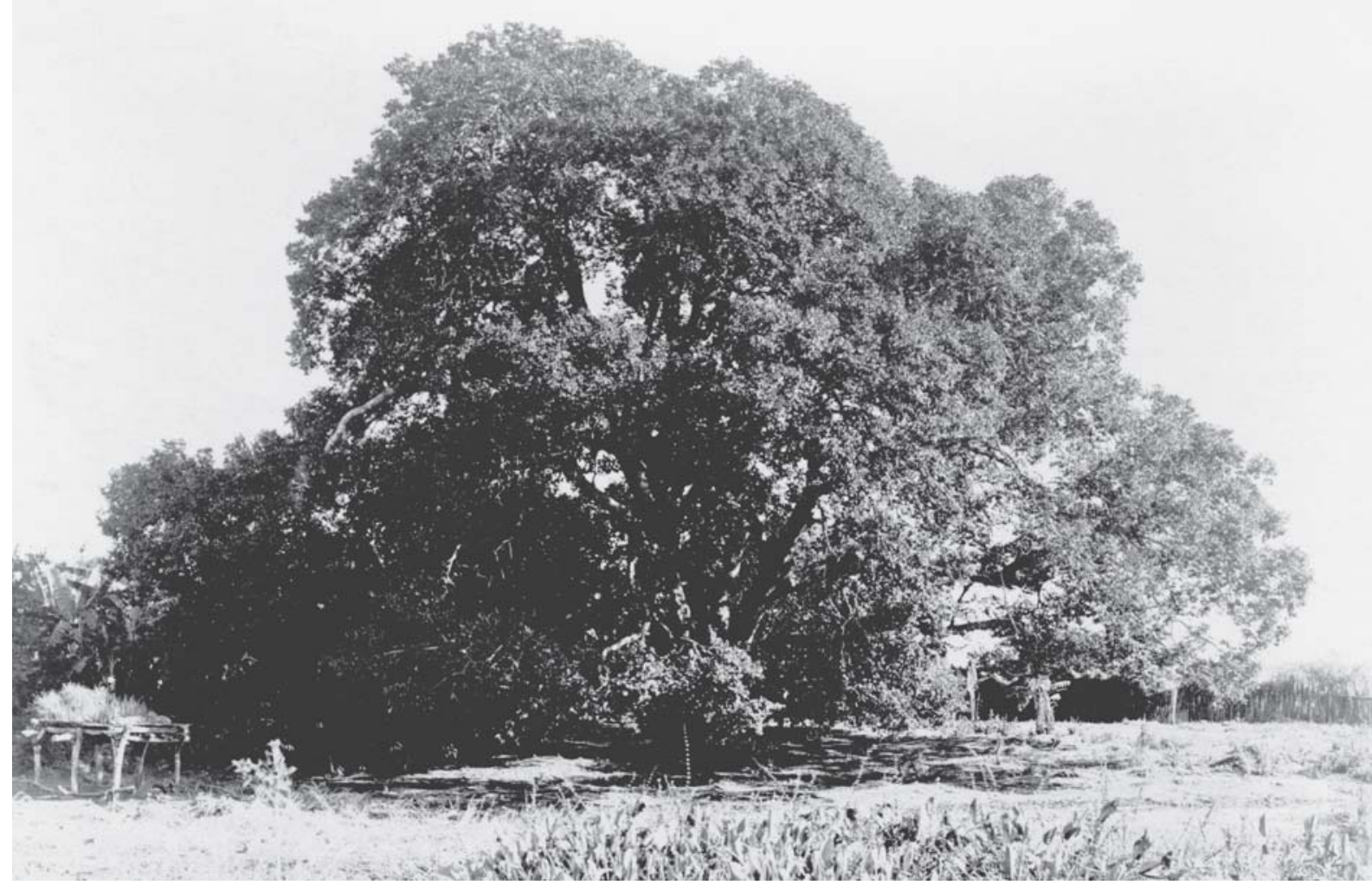

Figura 2: "Exemplar de jatobá excepcionalmente grande para aquelas paragens, pois os que existem às margens dos rios têm comumente menor desenvolvimento que nas regiões meridionais do país. Caracol, Piauí. 1912." (Neiva, Penna, 1916, estampa 3; arquivo Belisário Penna, Casa de Oswaldo Cruz/Fiocruz) 


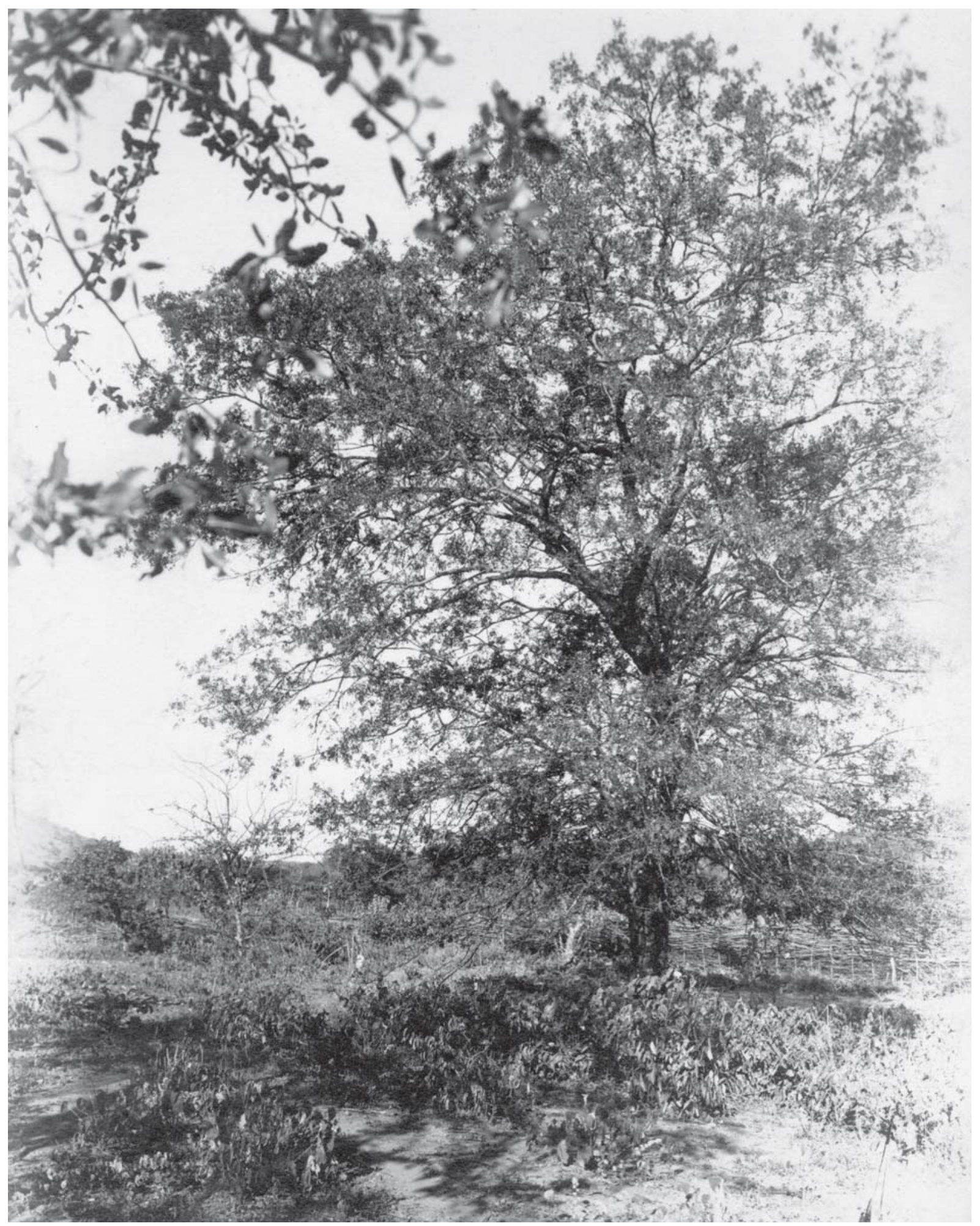

Figura 3: "Baraúna. São José da Canastra, Bahia. 1912". (Neiva, Penna, 1916, estampa 9; arquivo Belisário Penna, Casa de Oswaldo Cruz/Fiocruz) 

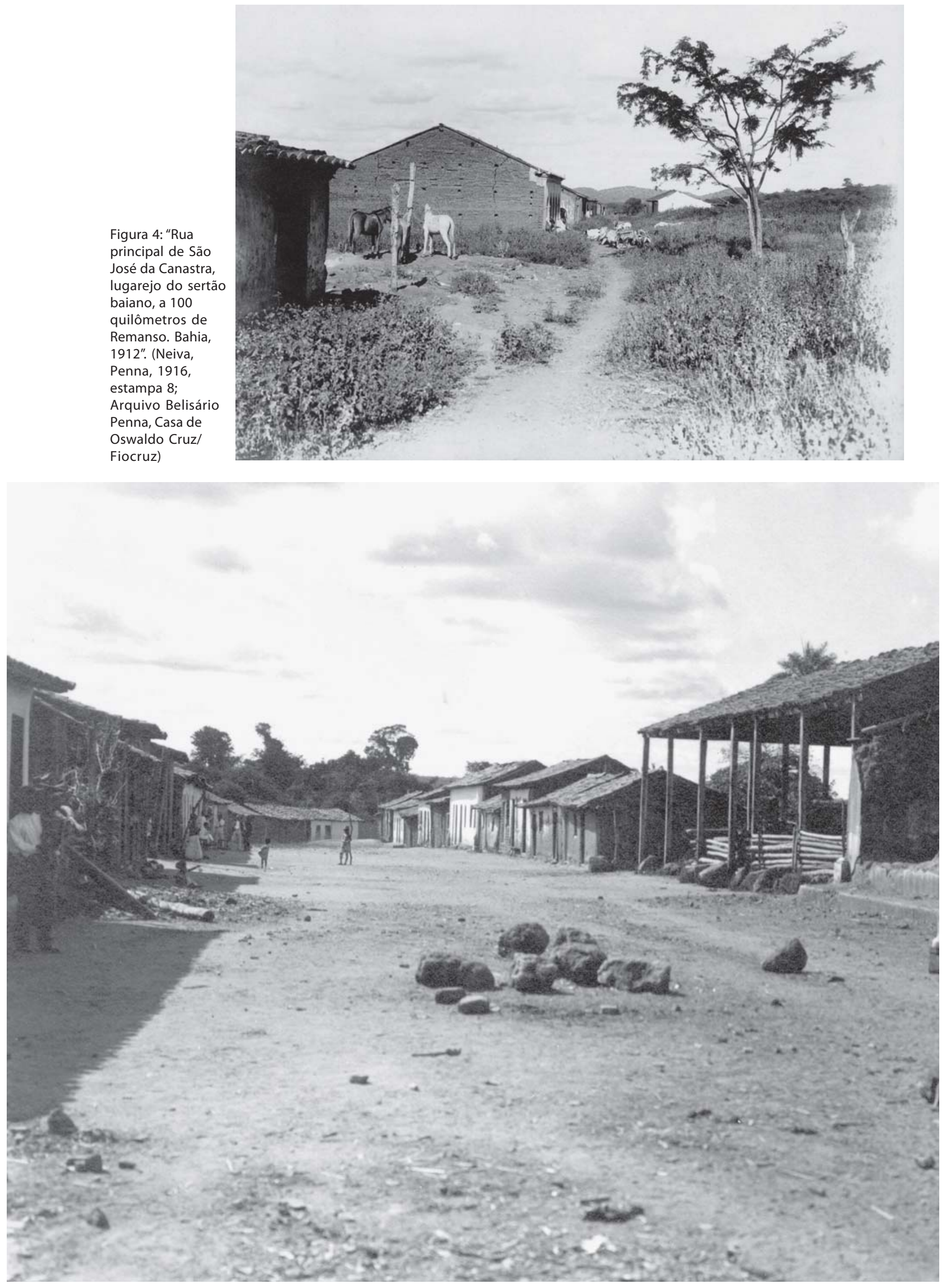


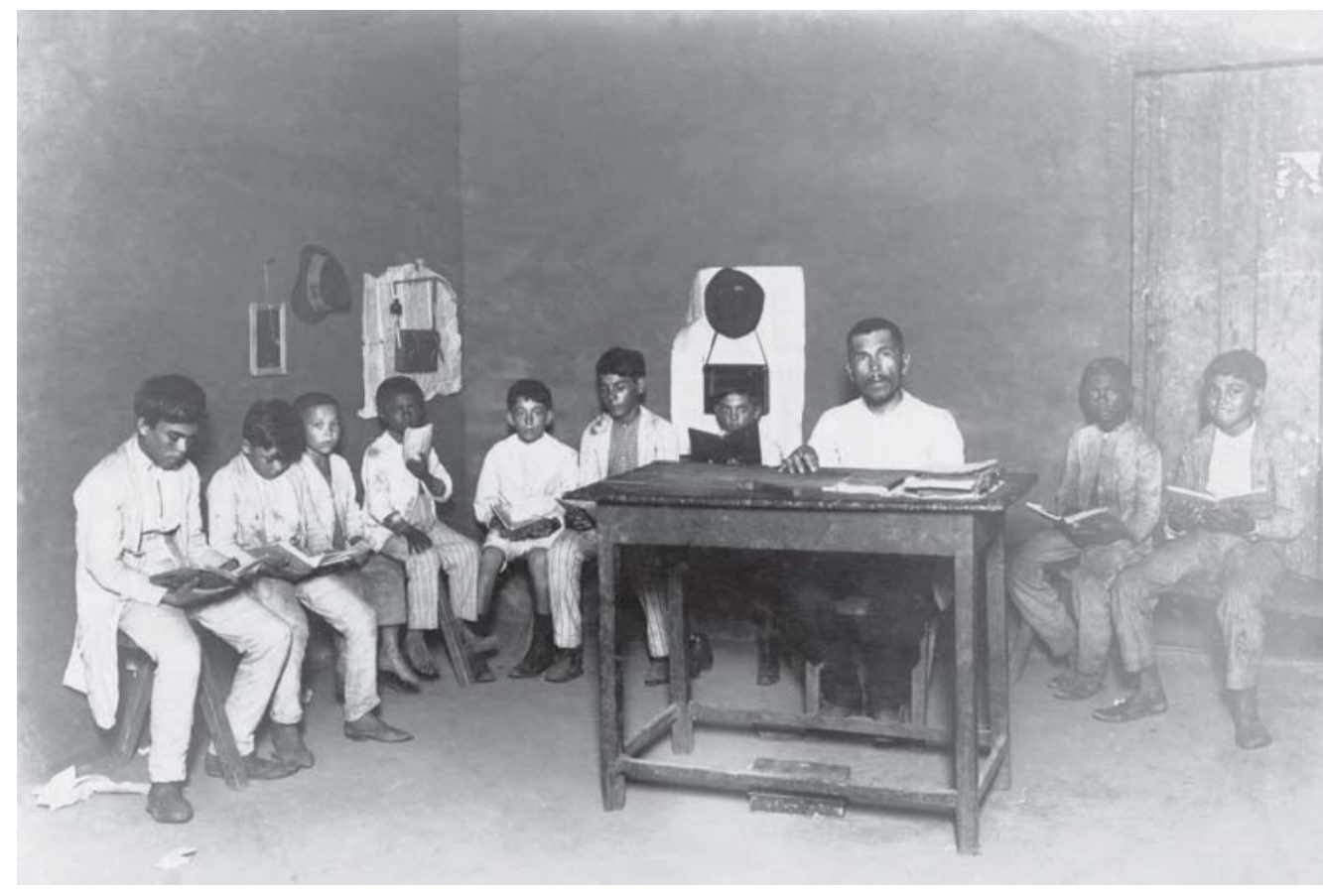

Figura 5: "Escola mantida pela iniciativa

particular em São Raimundo Nonato.

Piauí, 1912".

(Neiva, Penna,

1916, estampa 8; arquivo Belisário

Penna, Casa de Oswaldo Cruz/ Fiocruz)

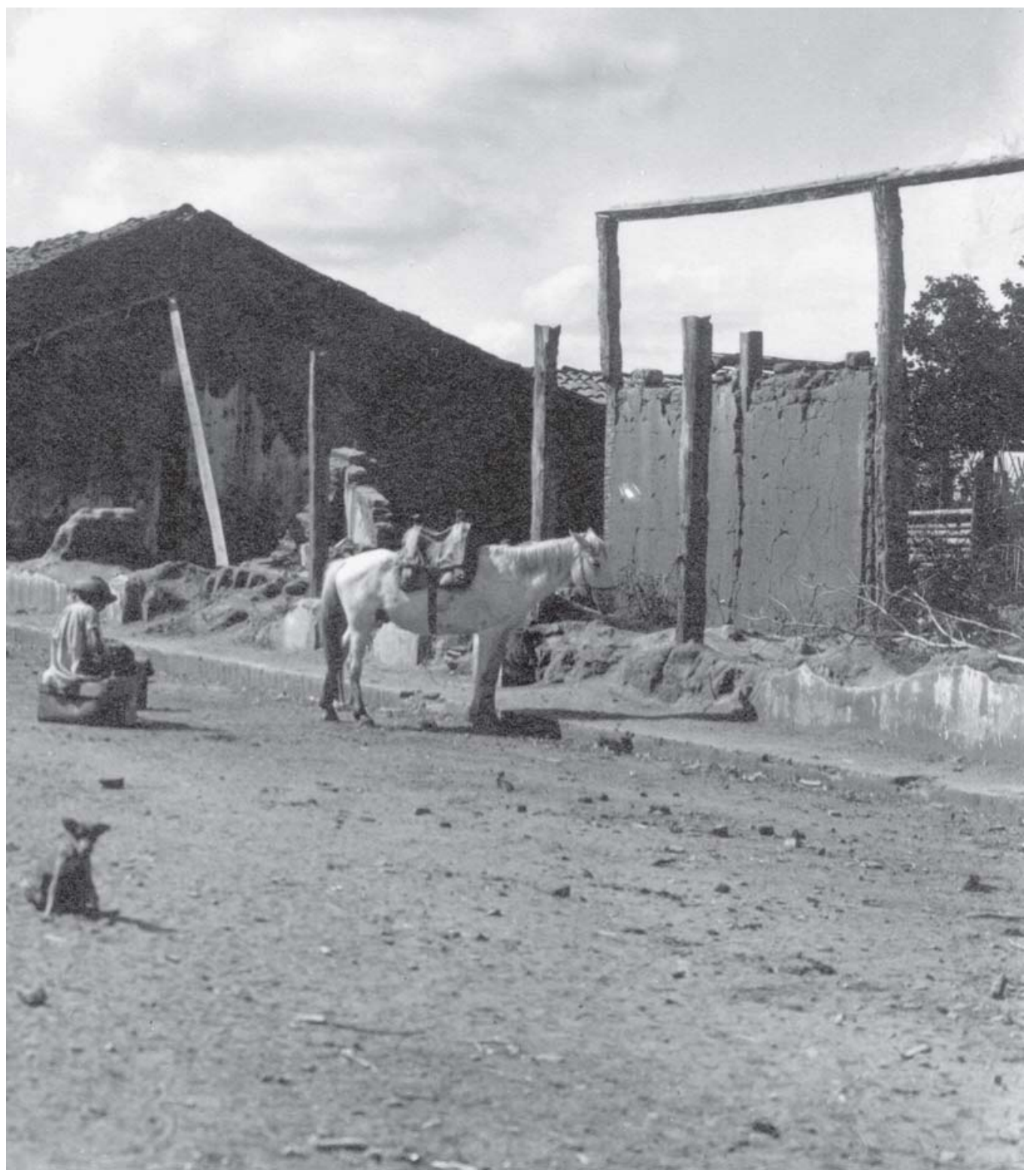

Figura 6: "Formosa, município de Santa Rita do Rio Preto. Rua principal mostrando vestígios das depredações ocasionadas por ocasião das lutas entre dois chefes locais. Bahia, 1912".

(Neiva, Penna,

1916, estampa 10; arquivo Belisário

Penna, Casa de

Oswaldo Cruz/ Fiocruz) 


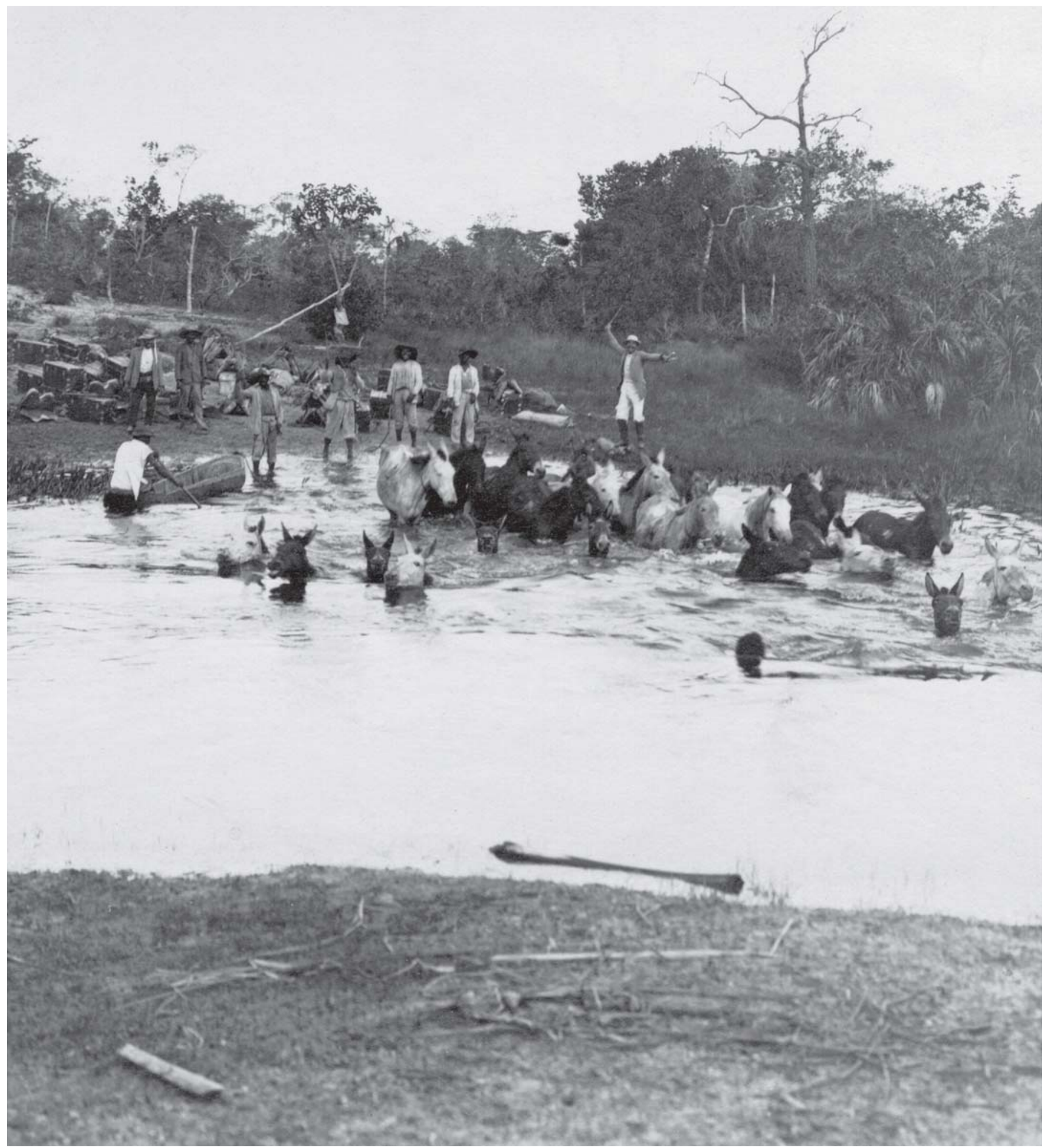

Figura 7: "Preparativos para passagem das bagagens da expedição. Cabeceiras do rio Preto. Bahia, 1912". (Neiva, Penna, 1916, estampa 15; arquivo Belisário Penna, Casa de Oswaldo Cruz/Fiocruz) 

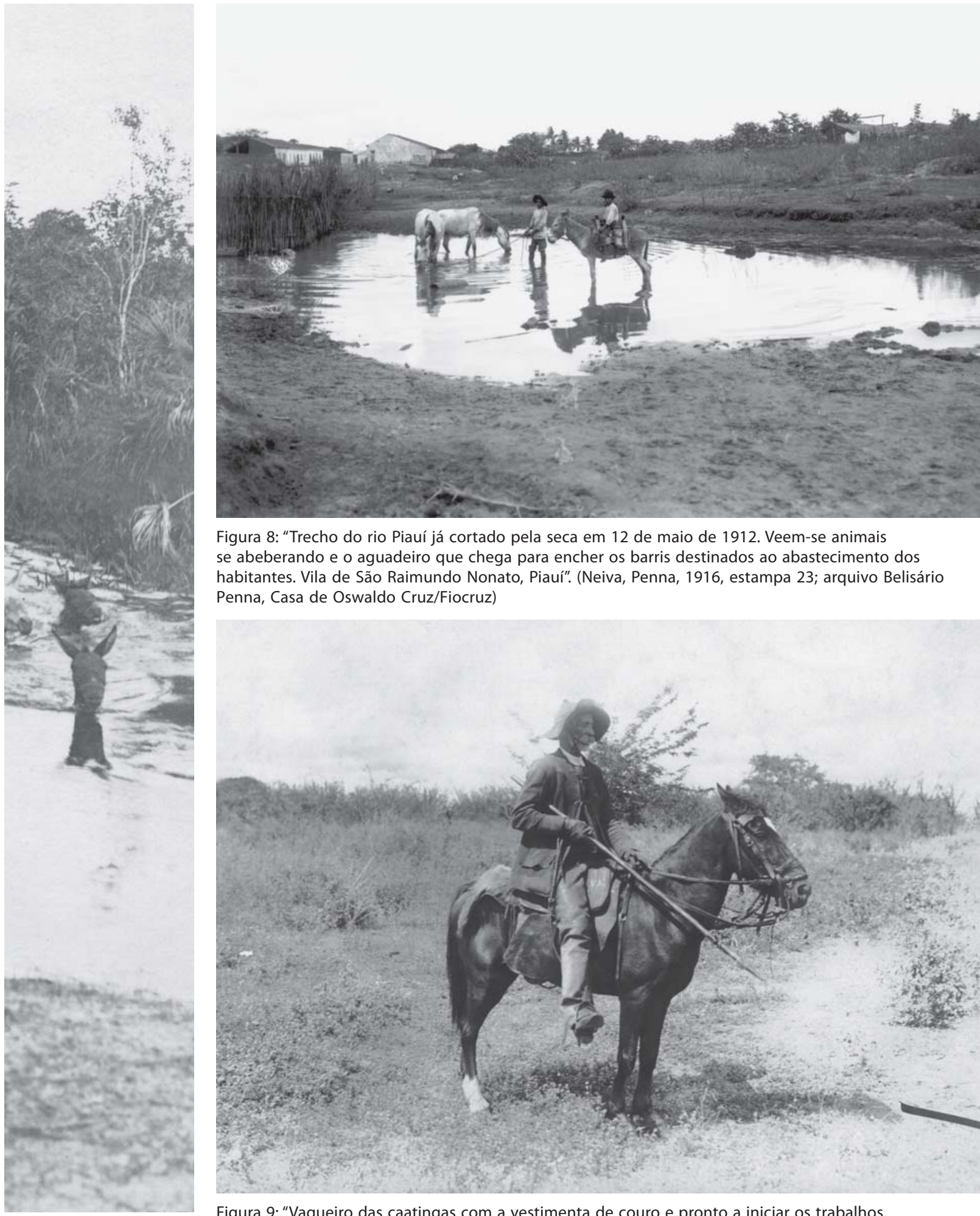

Figura 8: "Trecho do rio Piauí já cortado pela seca em 12 de maio de 1912. Veem-se animais se abeberando e o aguadeiro que chega para encher os barris destinados ao abastecimento dos habitantes. Vila de São Raimundo Nonato, Piauí". (Neiva, Penna, 1916, estampa 23; arquivo Belisário Penna, Casa de Oswaldo Cruz/Fiocruz)

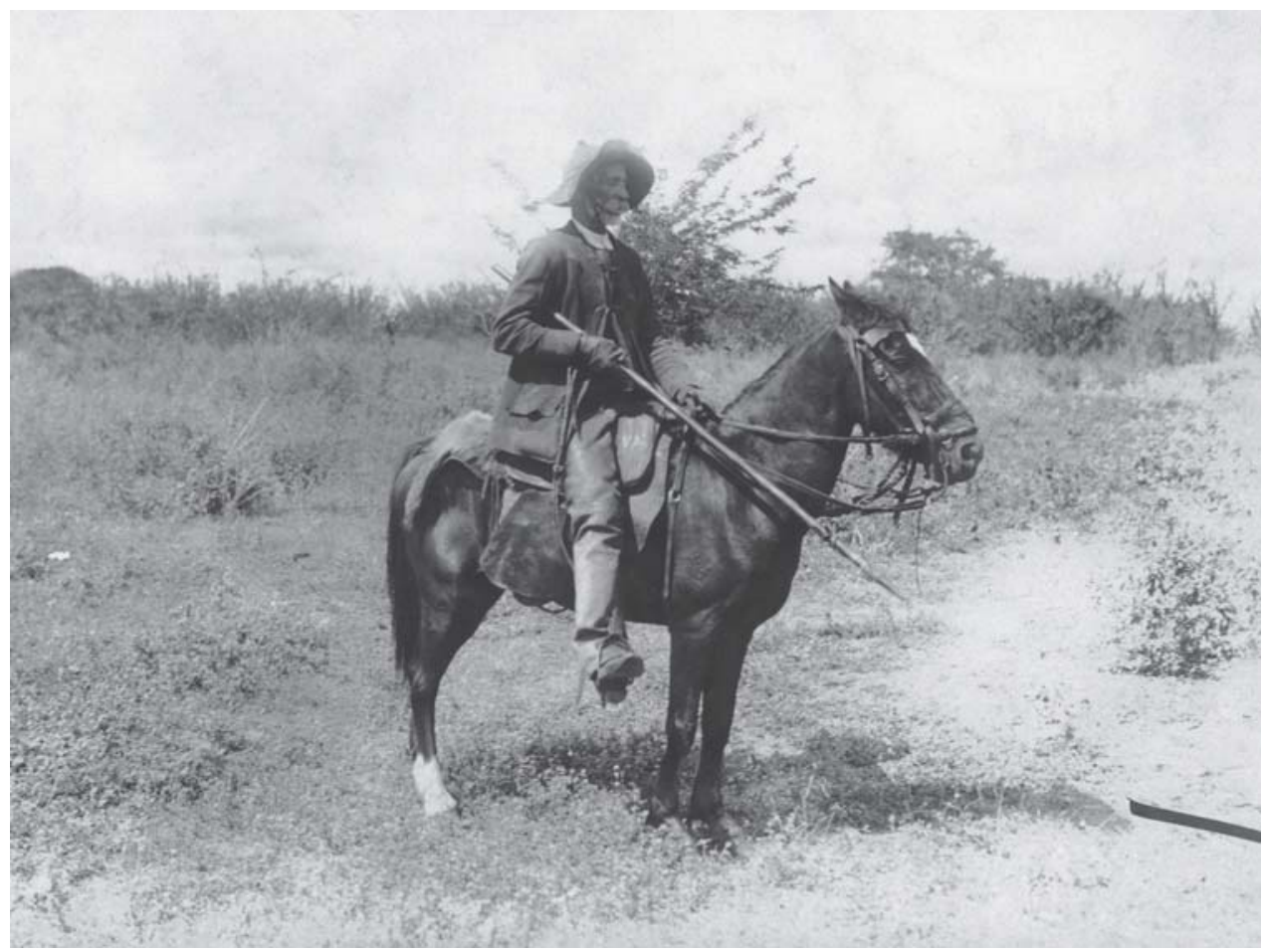

Figura 9: "Vaqueiro das caatingas com a vestimenta de couro e pronto a iniciar os trabalhos. Posição de descanso. Pernambuco, 1912." (Neiva, Penna, 1916, estampa 6; arquivo Belisário Penna, Casa de Oswaldo Cruz/Fiocruz) 


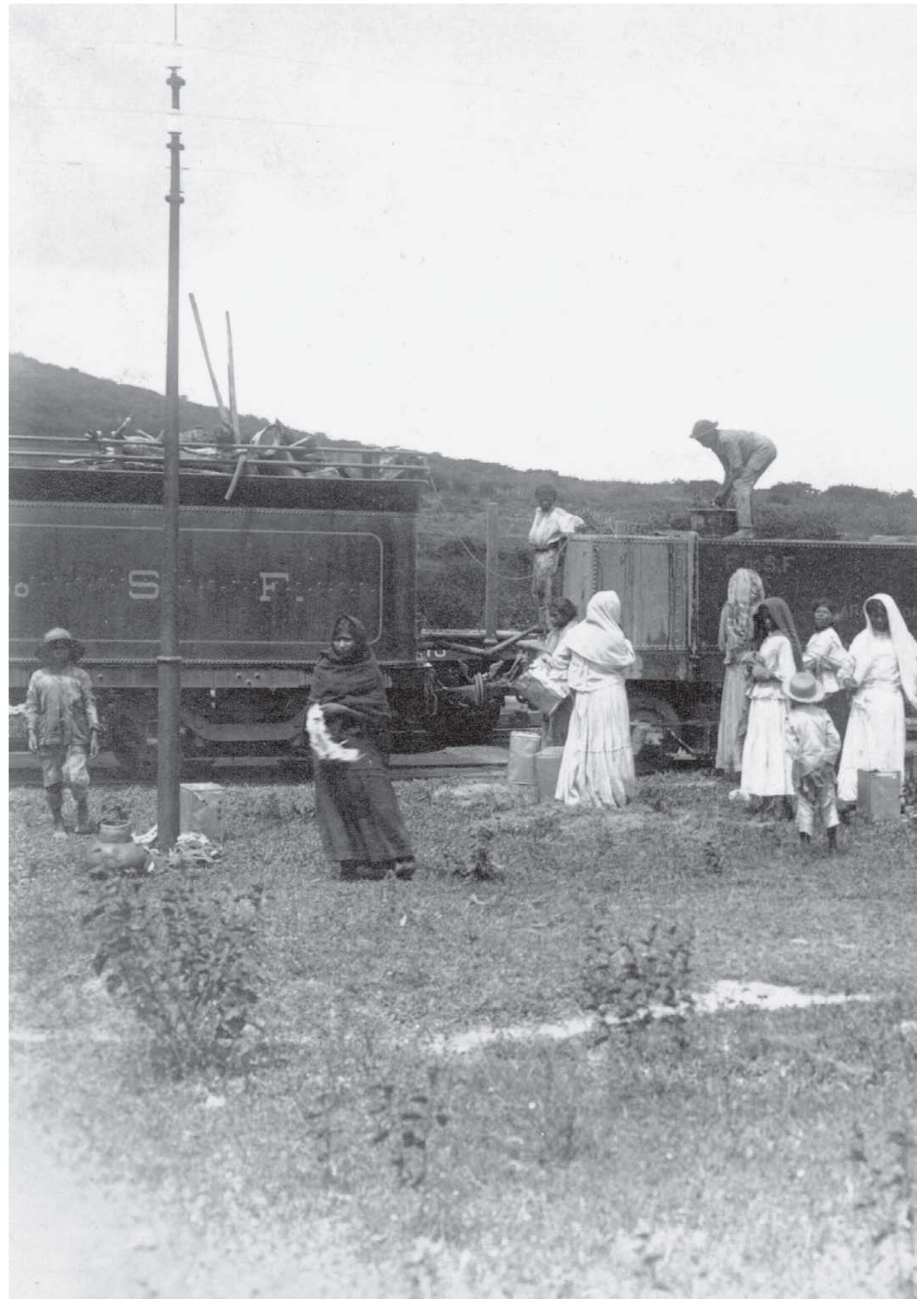


Figura 10: "Distribuição de água aos moradores de Jaguarari pelo trem de carreira da Estrada de Ferro São

Francisco. Bahia, 1912". (Neiva,

Penna, 1916, estampa 21; arquivo

Belisário Penna, Casa de Oswaldo

Cruz/Fiocruz)

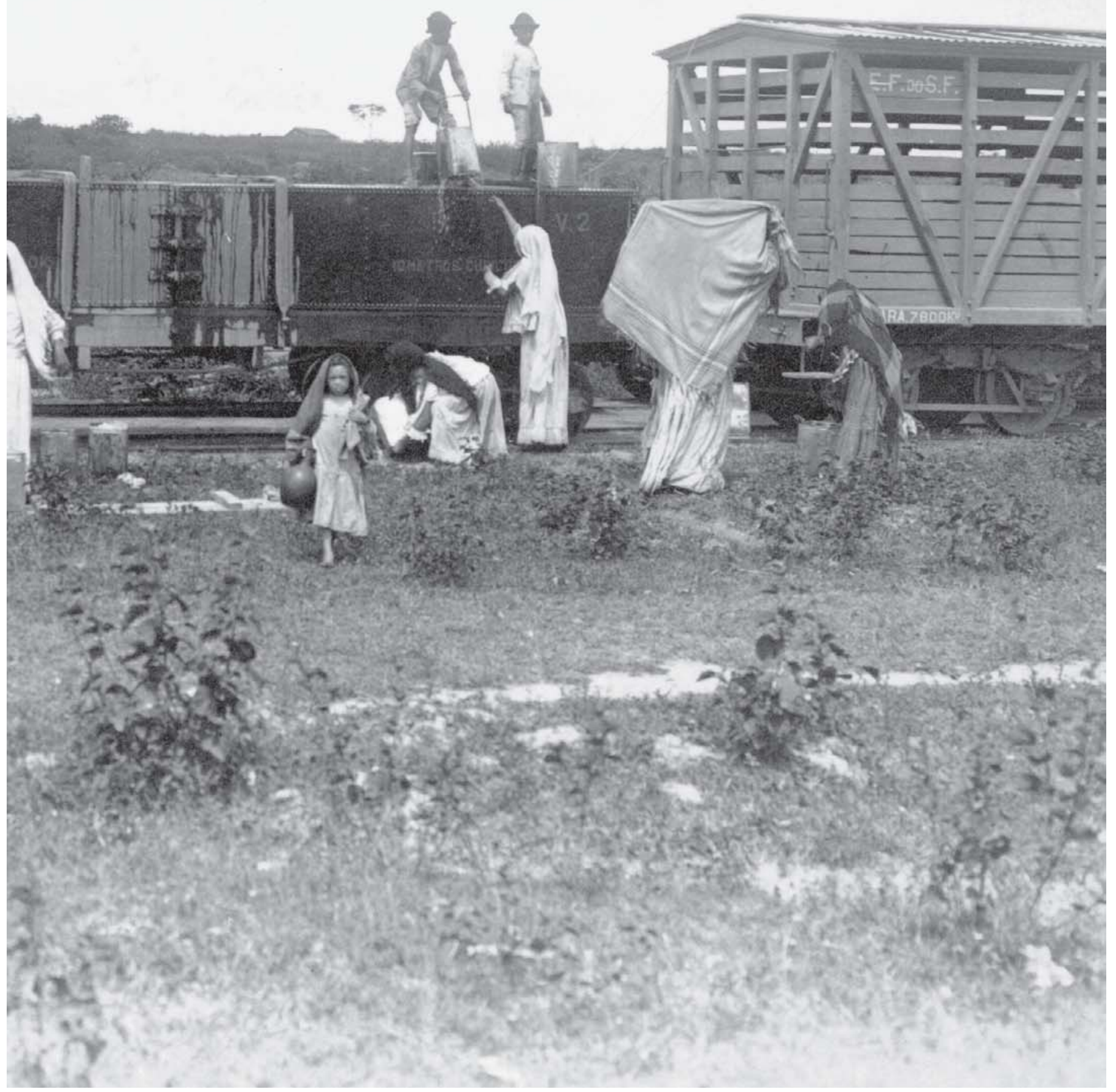




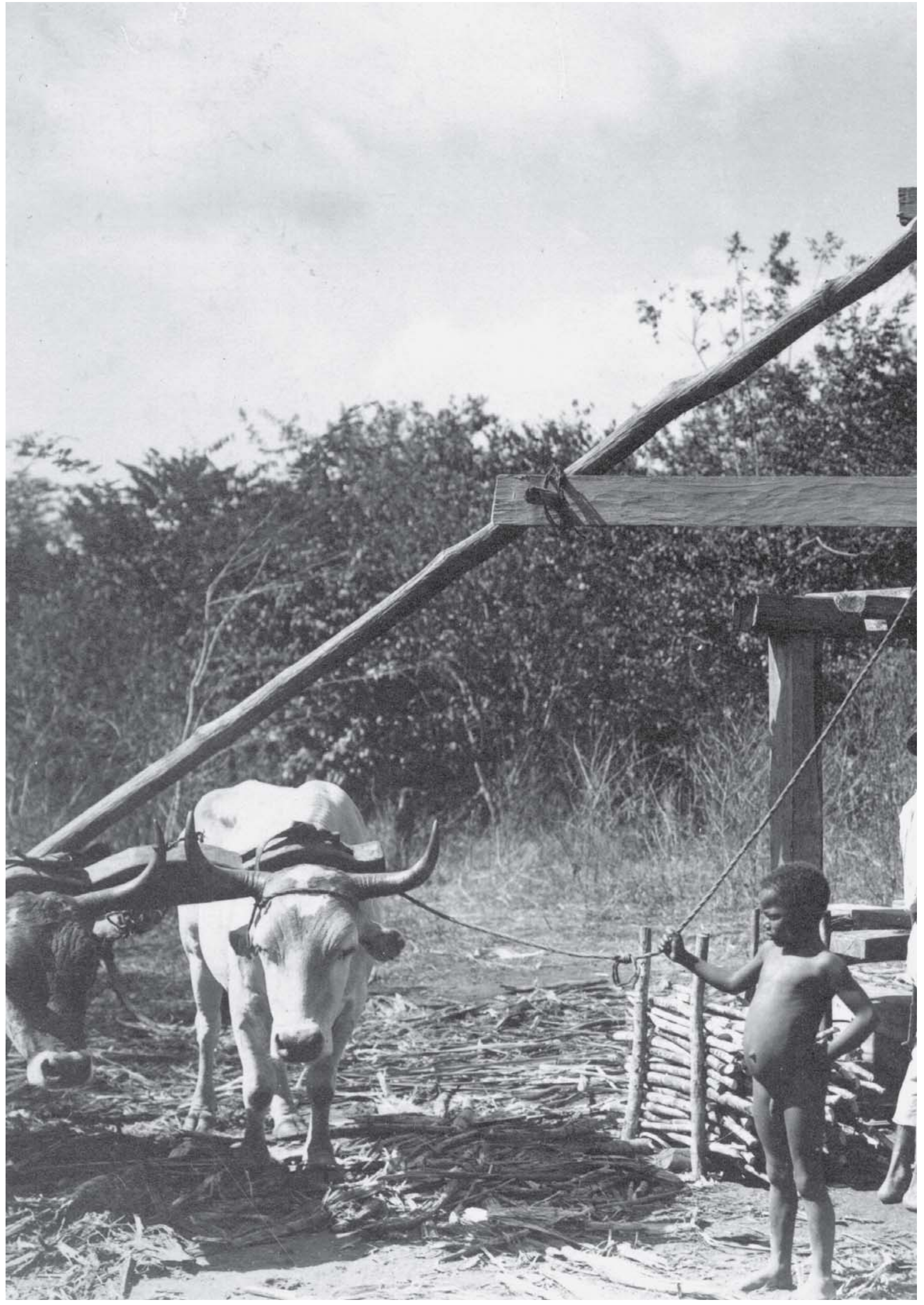




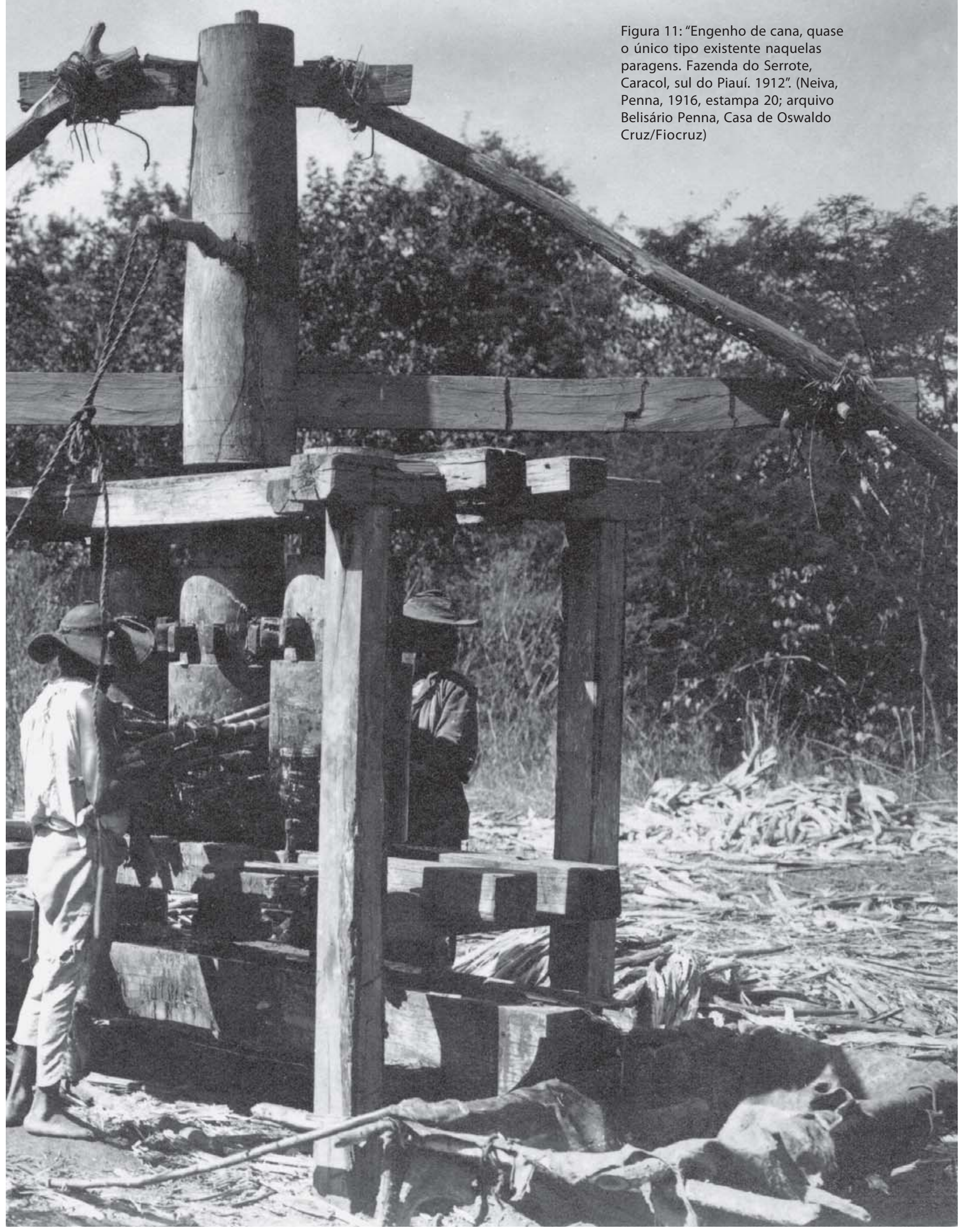



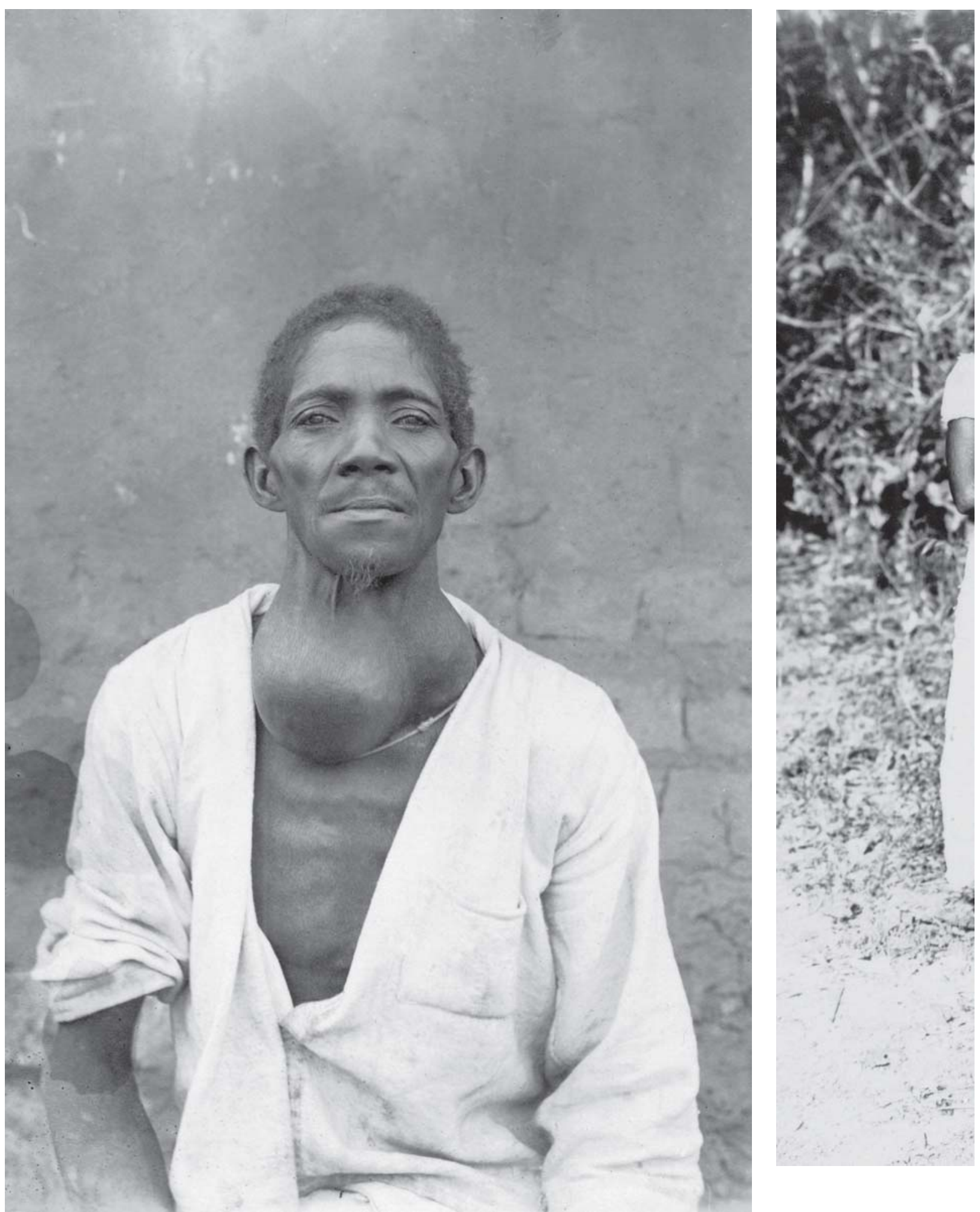

Figura 12: "Portador de bócio; inteligência pouco afetada. S.l., s.d.". (Neiva, Penna, 1916, estampa 25; arquivo Belisário Penna, Casa de Oswaldo Cruz/Fiocruz) 


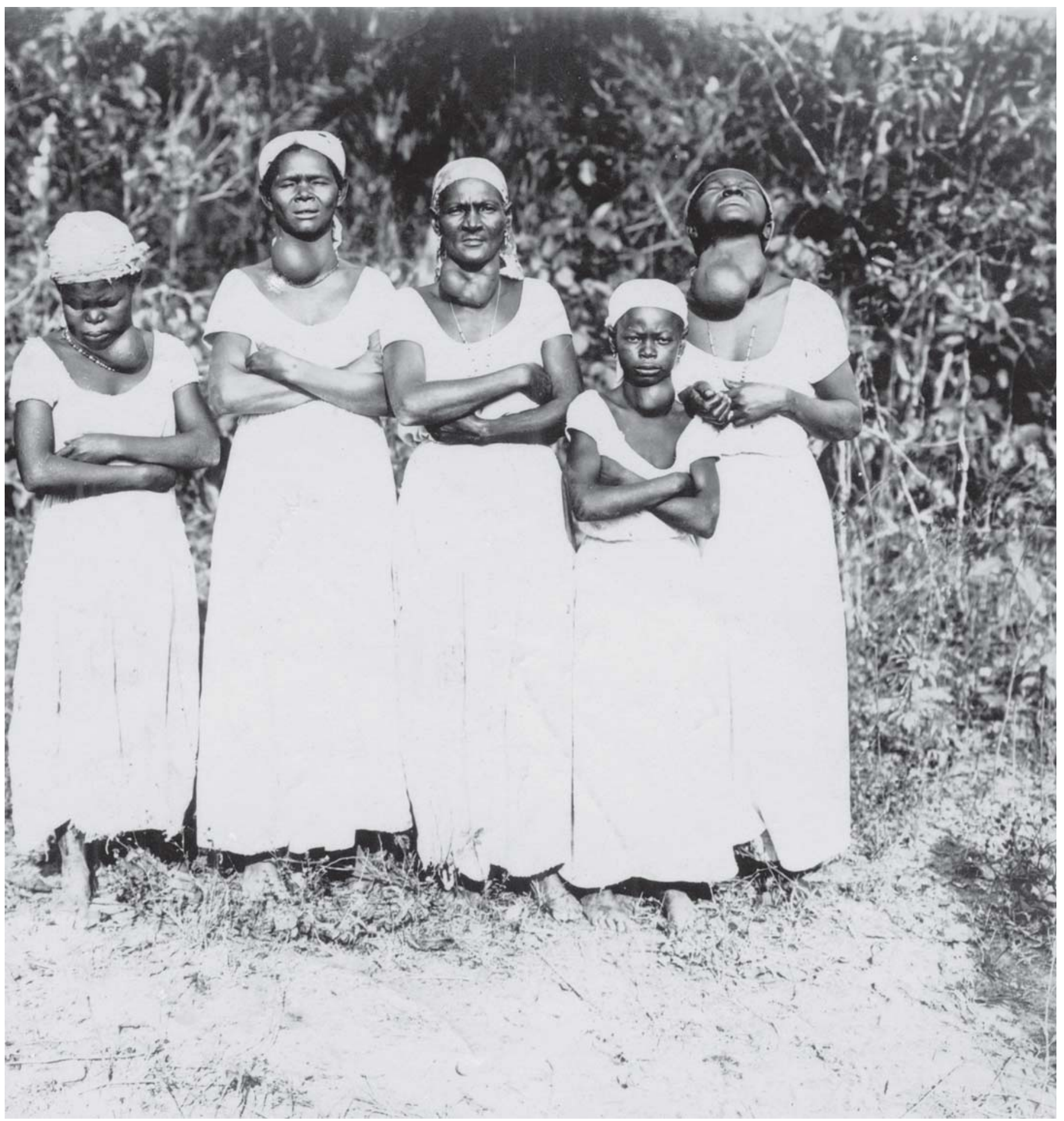

Figura 13: "A reprodução mostra a facilidade de se juntar um grupo de mulheres portadoras de grandes bócios. Submeteram-se tão facilmente à objetiva fotográfica porque o operador Ihes acenara com a esperança de radical cura, caso se deixassem ficar tranquilas diante da misteriosa máquina que pela primeira vez viam. Centro de Goiás, 1912". (Neiva, Penna, 1916, estampa 26; arquivo Belisário Penna, Casa de Oswaldo Cruz/Fiocruz) 


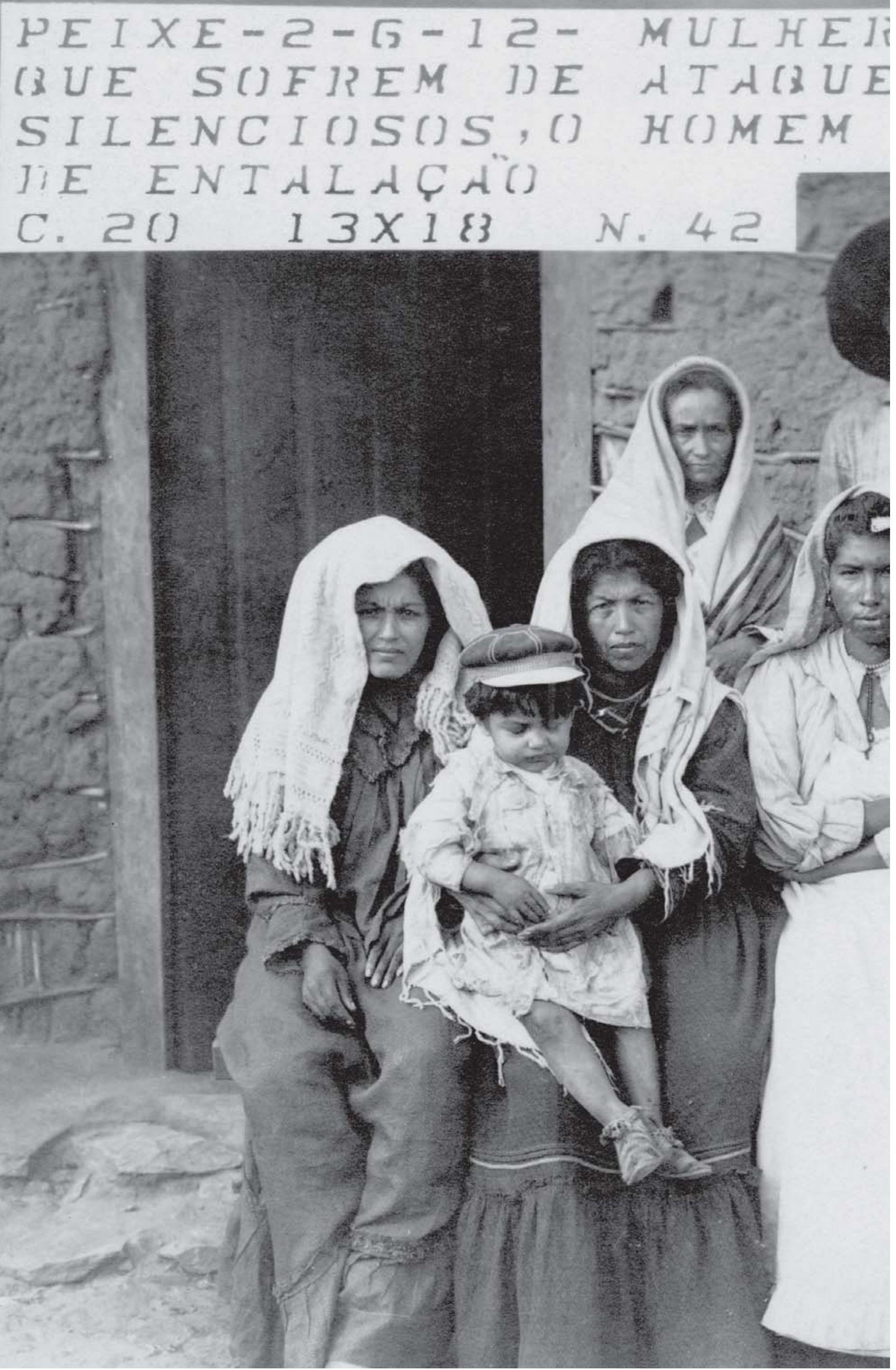




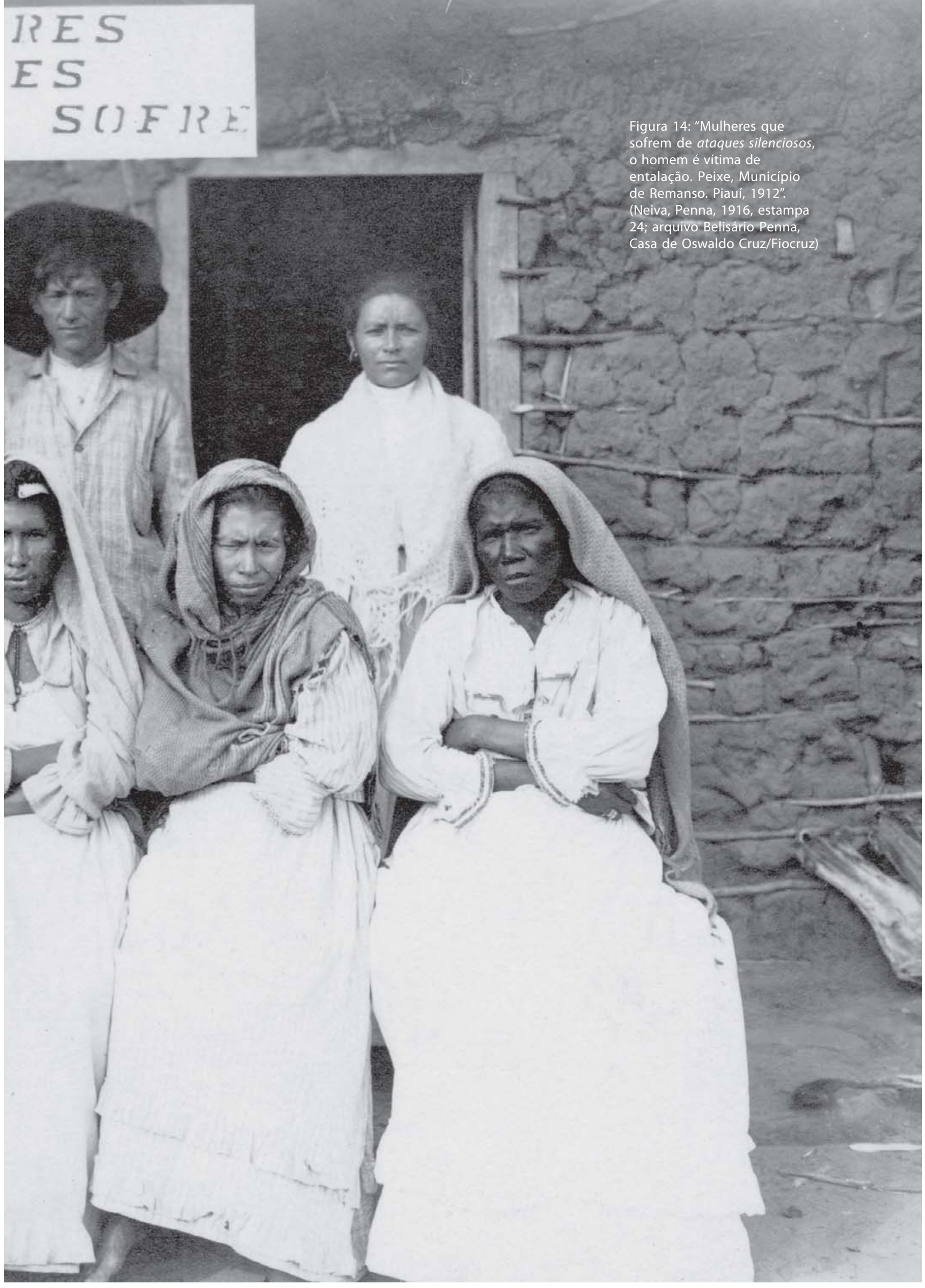

